\title{
Binuclear phthalocyanines covalently linked through two- and four-atom bridges ${ }^{1}$
}

\author{
Sebastian M. Marcuccio, Polina I. Svirskaya, Shafrira Greenberg, A. B. P. Lever, \\ AND ClifFord C. LEZNOFF ${ }^{2}$ \\ Department of Chemistry, York University, North York (Toronto), Ont., Canada M3J IP3 \\ AND \\ KENNETH B. TOMER \\ Midwest Center for Mass Spectrometry, Universitv of Nebraska-Lincoln, Lincoln, NE 68588, U.S.A.
}

\begin{abstract}
Sebastian M. Marcuccio, Polina I. Svirskaya, Shafrira Greenberg, A. B. P. Lever, Clifford C. Leznoff, and Kenneth B. TOMER. Can. J. Chem. 63, 3057 (1985).

Binuclear phthalocyanines in which the two phthalocyanine nuclei are covalently linked through four-atom bridges, derived from catechol, have been prepared and characterized. Metal-free 2,9,16,23-tetra-(3,3-dimethylbutyl)phthalocyanine and 2,9,16,23-tetra-(2-trimethylsilylethyl)phthalocyanine were prepared as examples of non-oxygenated mononuclear phthalocyanines soluble in organic solvents. Catalytic hydrogenation of 1,2-bis-(3,4-dicyanophenyl)ethyne and 1,4-bis-(3,4-dicyanophenyl)buta-1,3-diyne gave 1,2-bis-(3,4-dicyanophenyl)ethane and 1,4-bis-(3,4-dicyanophenyl)butane respectively. From these precursors, metal-free phthalocyanine dimers containing ethylene and tetramethylene bridges, joining the phthalocyanine nuclei, were prepared. Two of the two-atom bridge phthalocyanine dimers represent the first characterized phthalocyanine dimers not containing alkoxy or oxygenated groups.
\end{abstract}

Sebastian M. Marcuccio, Polina I. Svirskaya, Shafrira Greengerg, A. B. P. Lever, Clifford C. Leznoff et Kenneth B. TOMER. Can, J. Chem. 63, 3057 (1985).

On a préparé et on a caractérisé deux phtalocyanines binucléaires dans lesquelles deux noyaux phtalocyanines sont liés d'une façon covalente par quatre atomes de pont, dérivés du catéchol. On a préparé la tétra(diméthyl-3,3 butyl)-2,9,16,23 phtalocyanine et la tétra(triméthylsilyle-2 éthyle)-2,9,16,23 phtalocyanine exemptes de métal à titre d'exemples de phtalocyanines mononucléaires non oxygénées solubles dans des solvants organiques. Les hydrogénations catalytiques du bis(dicyano-3,4 phényl)-1,2 éthyne et du bis(dicyano- 3,4 phényl)-1,4 butadiyne-1,3 conduisent respectivement au bis(dicyano-3,4 phényl)-1,2 éthane et au bis(dicyano-3,4 phényl)-1,4 butane. À l'aide de ces précurseurs, on a préparé des phtalocyanines dimères sans métal contenant des ponts éthylènes et tétraméthylène entre les noyaux phtalocyanines. Deux de ces phtalocyanines dimères correspondent aux premières phtalocyanines ne contenant pas de groupements alkoxyles ou oxygénés à étre caractérisées.

The electrocatalytic properties of porphyrins and phthalocyanines have been the subject of intensive research (1). A dicobalt cofacial porphyrin dimer $(2,3)$ containing a four-atom covalent bridge has been prepared. The four-electron reduction of oxygen to water using this dimer has been achieved but the compound tends to lose its catalytic activity with time (2). Since the phthalocyanine nucleus is likely to be more stable (4) than the porphyrin nucleus, we have tried to synthesize the related, but hitherto unknown, phthalocyanine dimers. We have recently reported the synthesis and some properties of phthalocyanine dimers incorporating five-atom covalent bridges $(5,6)$. Unlike typical phthalocyanines, these dimers are very soluble in organic solvents and their great solubility facilitates their purification and characterization. Recent work on the synthesis of porphyrin dimers has shown that even dimers having one rigid covalent bridge can be held in a cofacial conformation thought to be necessary for electrocatalysis (7). Since a four-electron reduction of oxygen was not achieved using the five-atom bridge dimer (5), we wished to prepare phthalocyanine dimers separated by the key four-atom bridges $(2,3)$ and to provide binuclear phthalocyanines containing two-atom bridges or less as control electrocatalysts that cannot assume a cofacial conformation. In addition, we wished to study the possibility of synthesizing binuclear phthalocyanines

\footnotetext{
'Presented in part at the 67th Chemical conference of the Chemical Insitute of Canada, Montreal, Quebec, June 1984, Nos. IN5-5 and IN5-6.

${ }^{2}$ Author to whom correspondence may be addressed.
}

devoid of alkoxy groups or any oxygen atoms. In this paper we describe the preparation of a partially constrained binuclear phthalocyanine, containing a four-atom covalent bridge derived from catechol units; a flexible tetramethylene four-atom bridged phthalocyanine dimer; and phthalocyanine dimers containing two-atom ethylene bridges.

\section{Synthesis of binuclear phthalocyanines bridged covalently by} catechol units

Treatment of 4-nitrophthalonitrile (1) with 4-tert-butylcatechol ( $2 a$ ) or catechol $(\mathbf{2} b)$ and anhydrous potassium carbonate in dry dimethylformamide (DMF) at $22^{\circ} \mathrm{C}$ for $36 \mathrm{~h}$ gave $1,2-$ bis-(3,4-dicyanophenoxy)-4-tert-butylbenzene $(3 a)^{3}$ and 1,2 bis-(3,4-dicyanophenoxy)benzene $(3 b)^{3}$ in 84 and $78 \%$ yields, respectively $(9,10)$. Compounds $3 a, b$ were converted to their respective 1,3-diminoisoindolines $(4 a, b)$ by bubbling ammonia into a solution of $3 a$ or $3 b$ and sodium methoxide in dry methanol under reflux for $6 \mathrm{~h}$ or until an infrared spectrum of an aliquot of the reaction mixture no longer exhibited the typical nitrile absorption peak $(5,6,11,12)$. Condensation $(5,6$, $11,12)$ of $4 a$ with 5-neopentoxy-1,3-diiminoisoindoline (5) in $2-N, N$-dimethylaminoethanol for $60 \mathrm{~h}$ gave a green-black solution, which was diluted with water to give a blue coloured residue. Flash chromatography (13) of the residue taken up in toluene yielded, in the first fractions using toluene as eluant, $2,9,16,23$-tetraneopentoxyphthalocyanine $(6)(5,6)$ as a mix-

\footnotetext{
${ }^{3}$ See Table 1 for ${ }^{13} \mathrm{C}$ chemical shift values. Standard correlation tables were used as an aid to assignments (8).
} 
TABLE $1 .{ }^{13} \mathrm{C}$ nuclear magnetic resonance chemical shifts in ppm $(\delta)$ of some phthalonitriles and bisphthalonitriles

\begin{tabular}{ccccccccccc}
\hline & \multicolumn{10}{c}{ Compound } \\
\cline { 2 - 11 } Carbon $^{a}$ & $\mathbf{3 a ^ { b }}$ & $\mathbf{3 b}$ & $\mathbf{9}$ & $\mathbf{1 2}$ & $\mathbf{1 3}$ & $\mathbf{1 4}$ & $\mathbf{1 5}$ & $\mathbf{2 9}$ & $\mathbf{3 0}$ & $\mathbf{3 2}$ \\
\hline 1 & 109.4 & 109.9 & 113.8 & 115.0 & 115.2 & 112.5 & 112.1 & 115.2 & 112.4 & 114.0 \\
2 & 117.6 & - & 116.8 & 116.0 & 115.8 & 115.5 & 115.1 & 114.2 & 115.2 & 114.2 \\
3 & $120.8^{\circ}$ & $120.8^{c}$ & 141.9 & 135.9 & 135.6 & 132.7 & 133.1 & 136.2 & 132.7 & 133.8 \\
4 & 160.7 & 160.4 & 99.7 & 128.9 & 130.1 & 151.9 & 150.1 & 128.0 & 150.6 & 149.2 \\
5 & $120.6^{\circ}$ & $120.6^{c}$ & 142.4 & 136.2 & 135.9 & 133.3 & 122.6 & 136.5 & 133.3 & 134.2 \\
6 & 135.5 & 135.5 & 133.9 & 133.3 & 133.2 & 132.8 & 133.6 & 133.5 & 132.8 & 134.0 \\
7 & $115.2^{d}$ & $115.1^{d}$ & $114.9^{c}$ & $114.6^{c}$ & $113.6^{c}$ & 115.5 & $115.2^{r}$ & $114.5^{c}$ & $115.4^{c}$ & $116.1^{c}$ \\
8 & $114.9^{d}$ & $114.7^{\prime}$ & $114.9^{c}$ & $114.4^{c}$ & $114.8^{c}$ & 115.5 & $115.3^{r}$ & $114.8^{c}$ & $115.4^{c}$ & $116.6^{c}$ \\
9 & 144.1 & 144.9 & - & 103.2 & 106.7 & 30.0 & 44.8 & 84.4 & 28.4 & 36.0 \\
10 & 142.1 & 144.9 & - & 100.5 & 76.4 & 17.9 & 30.8 & 79.7 & 14.3 & 30.6 \\
11 & 123.0 & 123.7 & - & - & 28.1 & - & 30.0 & - & - & - \\
12 & 125.6 & 128.6 & - & -0.6 & 30.4 & -2.0 & 28.7 & - & - & - \\
13 & 152.8 & 128.6 & - & - & - & - & - & - & - & - \\
14 & $120.6^{\circ}$ & 123.7 & - & - & - & - & - & - & - & - \\
\hline
\end{tabular}

"The numbering of the carbon atoms in the compounds listed follows that given for these structures in the schemes and does not follow from the names of the compounds.

${ }^{b}$ The chemical shift values for the tert-butyl group are 34.9 and $31.1 \mathrm{ppm}$ for the quaternary and methyl groups respectively.

'These values may be interchanged.

"These values may be interchanged.

TABLE 2. Absorption spectra of mononuclear and binuclear phthalocyanines (pc) and their solubilities in $\mathrm{CH}_{2} \mathrm{Cl}_{2}{ }^{a}$

\begin{tabular}{cccccccc}
\hline \hline $\mathrm{Pc}$ & & \multicolumn{7}{c}{$\lambda_{\max }(\mathrm{nm})(\boldsymbol{\epsilon l o g})$} & & $\begin{array}{c}\text { Solubility } \\
\text { (mol/L) }\end{array}$ \\
\hline $7 a$ & $708(4.88)$ & $676(4.92)$ & $642(4.84)$ & $620(4.75)$ & $388(4.63)$ & $336(4.98)$ & $h^{\prime}$ \\
$\mathbf{7 b}$ & $698(4.83)$ & $666(4.93)$ & $638(4.94)$ & $618(4.84)$ & $384(4.67)$ & $334(5.08)$ & 0.1 \\
$\mathbf{7 c}$ & & $672(4.97)$ & & $628(4.90)$ & $326(4.91)$ & $290(5.03)$ & 0.06 \\
$\mathbf{1 8}$ & $698(5.25)$ & $664(5.19)$ & $644(4.81)$ & $604(4.59)$ & $342(5.02)$ & $292(4.76)$ & 0.7 \\
$\mathbf{1 9}$ & $698(5.11)$ & $664(5.05)$ & $644(4.67)$ & $604(4.45)$ & $342(4.88)$ & $290(4.58)$ & 0.1 \\
$\mathbf{2 0}^{c}$ & & $672(5.04)$ & & $608(4.45)$ & $330(4.75)$ & $290(4.72)$ & $<10^{-5}$ \\
$\mathbf{2 5}^{c}$ & $702(4.86)$ & $668(4.92)$ & $642(4.90)$ & $620(4.83)$ & $340(5.08)$ & $292(4.81)$ & $<10^{-6}$ \\
$\mathbf{2 6}^{c}$ & $702(4.93)$ & $666(4.96)$ & $644(4.90)$ & $618(4.81)$ & $340(5.10)$ & $292(4.85)$ & $<10^{-6}$ \\
$\mathbf{2 7}^{d}$ & $706(4.98)$ & $672(5.03)$ & $646(4.96)$ & $620(4.86)$ & $344(5.05)$ & $296(4.79)$ & $<10^{-5}$ \\
$\mathbf{2 8}^{d}$ & & $680(4.99)$ & & $626(4.69)$ & $336(4.87)$ & $296(5.02)$ & $<10^{-5}$ \\
$\mathbf{3 4}^{d}$ & $708(4.94)$ & $672(5.02)$ & $644(4.99)$ & $620(4.87)$ & $342(5.09)$ & $296(5.02)$ & $<10^{-5}$ \\
\hline
\end{tabular}

"Solubilities were determined at $24^{\circ} \mathrm{C}$ by visible spectroscopy of saturated solutions in $\mathrm{CH}_{2} \mathrm{Cl}_{2}$.

${ }^{b} \mathrm{Available} \mathrm{small}$ quantities of $7 a$ were insufficient to obtain reliable data on this very soluble dimer.

'These absorption spectra were taken in $\mathrm{CHCl}_{3}$.

"These absorption spectra were taken in $o$-dichlorobenzene.

ture of isomers. Further elution with toluene gave mixtures of

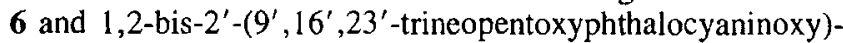
4-tert-butylbenzene ( $7 a$ ) and some later fractions of pure $7 a$ as shining dark purple plates. ${ }^{4}$ Repetitive flash chromatography of the mixed fractions 6 and $7 a$ gave pure $7 a$ in $13 \%$ overall yield (Scheme 1). We initially selected 4-tert-butylcatechol (2a) as the bridging moiety of binuclear phthalocyanines so that the resultant phthalocyanine dimer would be soluble in organic solvents. This idea was realized but $7 a$ was actually too mobile chromatographically so that separation from the monomer 6 was tedious. The above synthesis was subsequently repeated but using catechol $(2 b)$ as the bridging group. Thus, the 1,3-diiminoisoindoline $(4 b)$ was condensed with 5 as before. Flash

\footnotetext{
${ }^{4}$ Continued elution with toluene and toluene/2-methoxyethanol mixtures gave an additional blue-green fraction which, by fast atom bombardment analysis (FAB) (14), was shown to have a molecular ion corresponding to a phthalocyanine trimer.
}

chromatography (13) of the resultant blue-green mixture was much more facile, as monomer 6 eluted first in toluene, followed by mixed monomer-dimer fractions using toluene and toluene/2-methoxyethanol $(50: 1)$ as eluants. ${ }^{4}$ Rechromatography of the mixed fractions gave pure $1,2-$ bis- $2^{\prime}-\left(9^{\prime}, 16^{\prime}, 23^{\prime}\right.$ trineopentoxyphthalocyaninoxy)benzene $(7 b)$ in $10 \%$ yield. Phthalocyanine dimer $7 b$ was readily converted to its dicobalt(II) derivative $7 c$ by heating $7 b$ with $\mathrm{CoCl}_{2}$ in toluene at $110^{\circ} \mathrm{C}$ for $30 \mathrm{~h}$. Dimer $7 c$ was purified as before by flash chromatography using toluene/2-methoxyethanol $(50: 1)$ as eluant. The structures of $3 a, b$ and $7 a-c$ have been fully characterized by spectroscopic data and elemental analysis (see Experimental). The absorption spectra of $7 a-c$ are characteristic of metal-free and metallophthalocyanine dimers respectively (6) (Table 2). Most importantly, the fast atom bombardment (14) (FAB) mass spectra of the binuclear phthalocyanines $7 a-c$ all exhibit parent ion clusters almost identical in intensity to those calculated for their respective isotopic compositions. It 

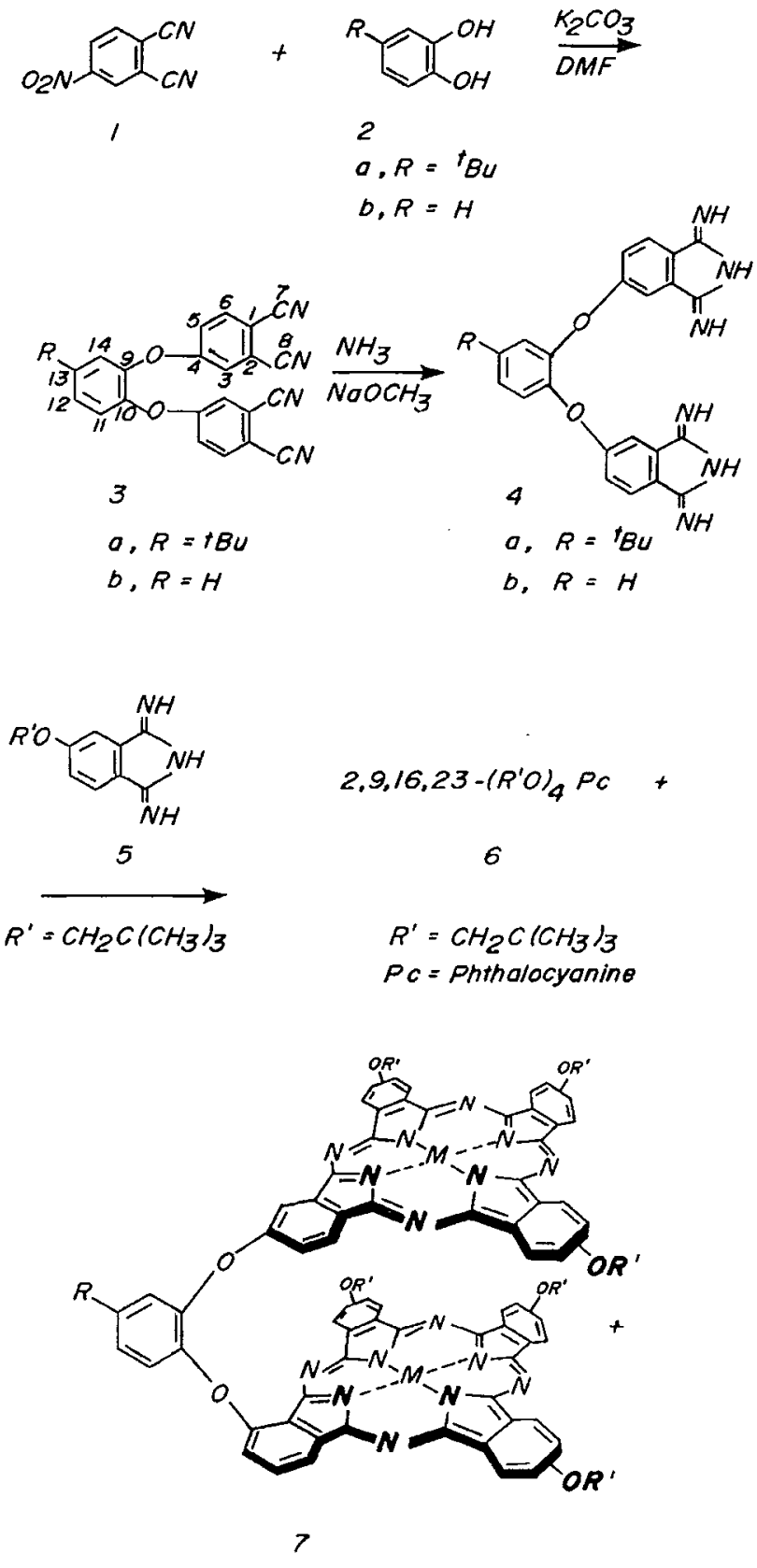

$$
\begin{array}{ll}
a, R=I_{B U}, & \left.R^{\prime}=\mathrm{CH}_{2} \mathrm{ClCH}_{3}\right)_{3}, M=\mathrm{H}_{2} \\
b, R=H, & \left.R^{\prime}=\mathrm{CH}_{2} \mathrm{ClCH}_{3}\right)_{3}, M=\mathrm{H}_{2} \\
c, R=H, & \left.R^{\prime}=\mathrm{CH}_{2} \mathrm{ClCH}_{3}\right)_{3}, M=\mathrm{CO}
\end{array}
$$

SCHEME 1

should be noted, however, that phthalocyanines $7 a-c$ exist as a mixture of positional isomers about the phthalocyanine ring and that the depicted structure thus reflects this mixture. The broad absorbances in the ' $\mathrm{H}$ nmr spectra of these compounds are indicative of this isomeric distribution (Table 3 ). On the other hand, the ${ }^{13} \mathrm{C}$ nmr spectra of $7 a$ and $7 b$ exhibit single resonances for the methyl and quaternary carbon groups of the neopentoxy substituents. Thus ${ }^{13} \mathrm{C} \mathrm{nmr}$ spectra of $7 a, b$ are diagnostic concerning their skeletal structure (Table 4), while the $\mathrm{H}$ nmr spectra clearly identify the internal $\mathrm{NH}$ protons of $7 a, b$ (Table 3 ).

Synthesis of 2,9,16,23-tetraalkylphthalocyanines

It has been shown $(15,16)$ that a wide variety of alkynes can couple with iodoarenes even at room temperature using cuprous iodide and bis(triphenylphosphine)palladium dichloride. We believed that this reaction could provide the basis for preparing the 4-alkylphthalonitriles and bisphthalonitriles needed for the preparation of mono and binuclear phthalocyanines containing no alkoxy substituents or oxygen atoms in the bridges of the phthalocyanines.

Catalytic hydrogenation of 1 in ethanol using $10 \%$ palladium on charcoal yielded 4-aminophthalonitrile (8) in $84 \%$ yield. Diazotization of 8 and subsequent reaction of the first-formed diazonium salt with potassium iodide gave 4-iodophthalonitrile $(9)^{3}$ in high yield. Coupling of 9 with trimethylsilylacetylene (10) (16) or 3,3-dimethyl-1-butyne (11) $(15,16)$ gave 4-(2-trimethylsilylethynyl)phthalonitrile $(\mathbf{1 2})^{3}$ or 4 -(3,3-dimethyl-1butynyl)phthalonitrile $(\mathbf{1 3})^{3}$ in $75 \%$ and $75 \%$ yield, respectively. Hydrogenation of 12 and 13 using palladium on charcoal as a catalyst gave the corresponding 4-alkyl derivatives, 4-(2-trimethylsilylethyl)phthalonitrile $(14)^{3}$ and 4-(3,3-dimethylbutyl)phthalonitrile $(\mathbf{1 5})^{3}$ in high yield. Conversion of 14 and 15 to their 1,3-diiminoisoindolines (16) and (17) as before $(5,6$, $11,12)$ and subsequent self-condensation in $2-N, N$-dimethylaminoethanol gave 2,9,16,23-tetra-(2-trimethylsilylethyl)phthalocyanine (18) and 2,9,16,23-tetra-(3,3-dimethylbutyl)phthalocyanine (19) in $28 \%$ and $40 \%$ yields, respectively (Scheme 2). Phthalocyanine (19) was readily converted to its cobalt(II) derivative (20) as before $(6,11)$.

The mass spectra of 18-20 exhibited parent ions using the FAB technique (14). The ' $\mathrm{H}$ nmr spectra of 18 and 19 were most informative and showed the inner $\mathrm{NH}$ absorptions (Table 3). In addition, the trimethylsilyl group of $\mathbf{1 8}$ and the tert-butyl group of 19 showed four and six peaks, respectively, corresponding to the eight different environments that these groups may experience in the four isomers possible for a tetrasubstituted phthalocyanine containing one substituent on each benzene ring. For 2,9,16,23-tetraneopentoxyphthalocyanine (6), the tert-butyl group gave an unresolved broad absorption peak in its ' $\mathrm{H}$ nmr spectrum when recorded at high concentrations (6) but also exhibited 6 individual absorption peaks at lower concentrations (Table 3).

The ${ }^{13} \mathrm{C}$ nmr spectra of 18 and 19 exhibited only two peaks for the trimethyl group and the tert-butyl group while 6 showed only a single peak. On the other hand the $-\mathrm{SiCH}_{2}-$ group and $-\mathrm{Si}-\mathrm{CH}_{2} \mathrm{CH}_{2}-$ groups exhibited 8 and 6 peaks, respectively, indicating that all four isomers of 18 were indeed present (Table 4). Comparison of the solubilities of 18 and 19 with 6 showed that the tetraalkylphthalocyanines were less soluble than the tetraalkoxyphthalocyanine (6) (Table 2). The absorption spectra of 18 and 19 were consistent with the assigned structures (Table 2) (6).

Preparation of binuclear phthalocyanines covalently linked by dimethylene bridges

The dicoupling (15) of an acetylene to an jodoarene should provide the unknown bisphthalonitriles necessary to form binuclear phthalocyanines containing an all-carbon bridging group.

Thus treatment of 4-iodophthalonitrile (9) by methods previously described with acetylene (21) gave 1,2-bis-(3,4-dicyanophenyl)ethyne (22) in $90 \%$ yield. Compound 22 was very 


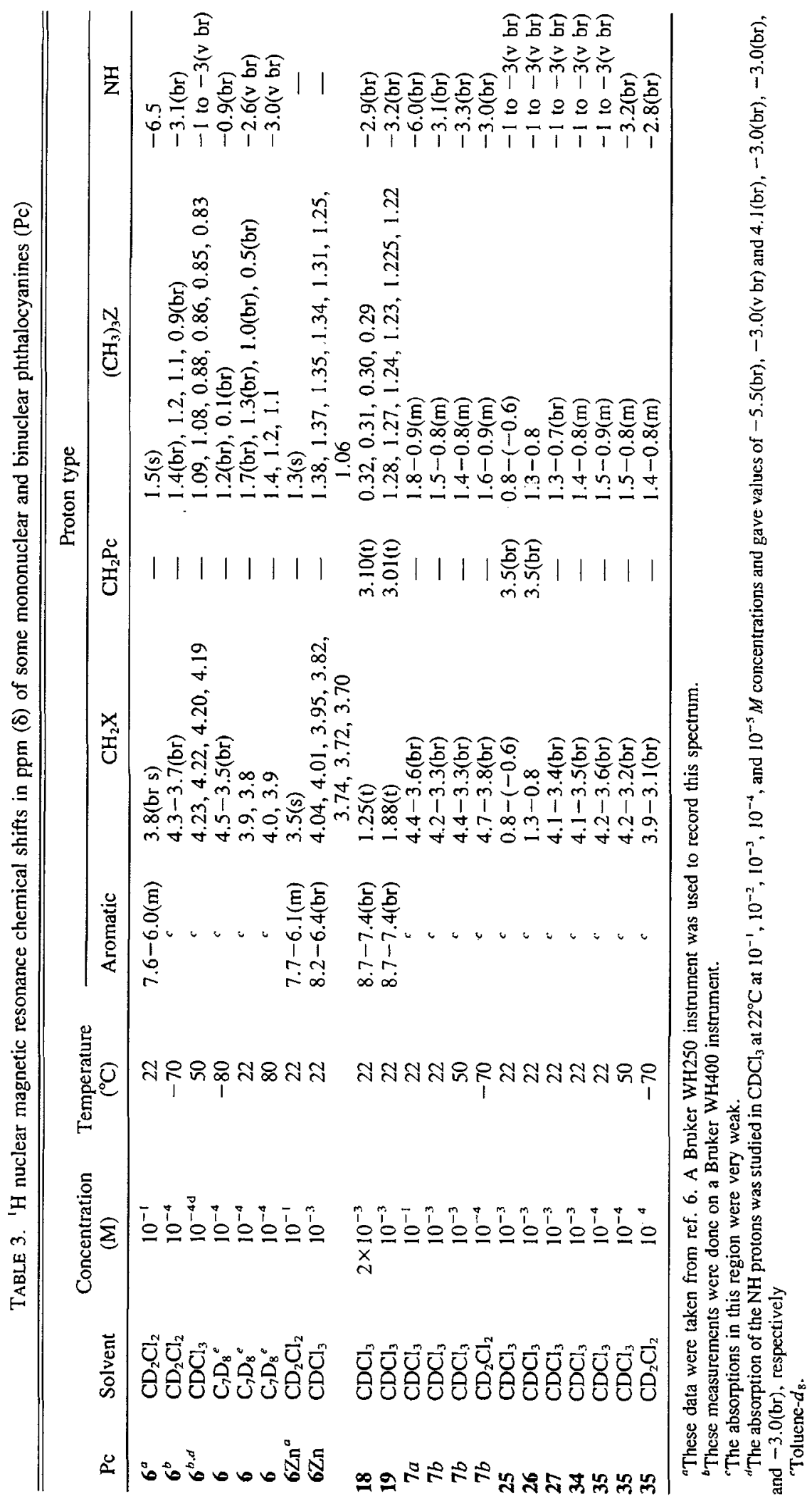



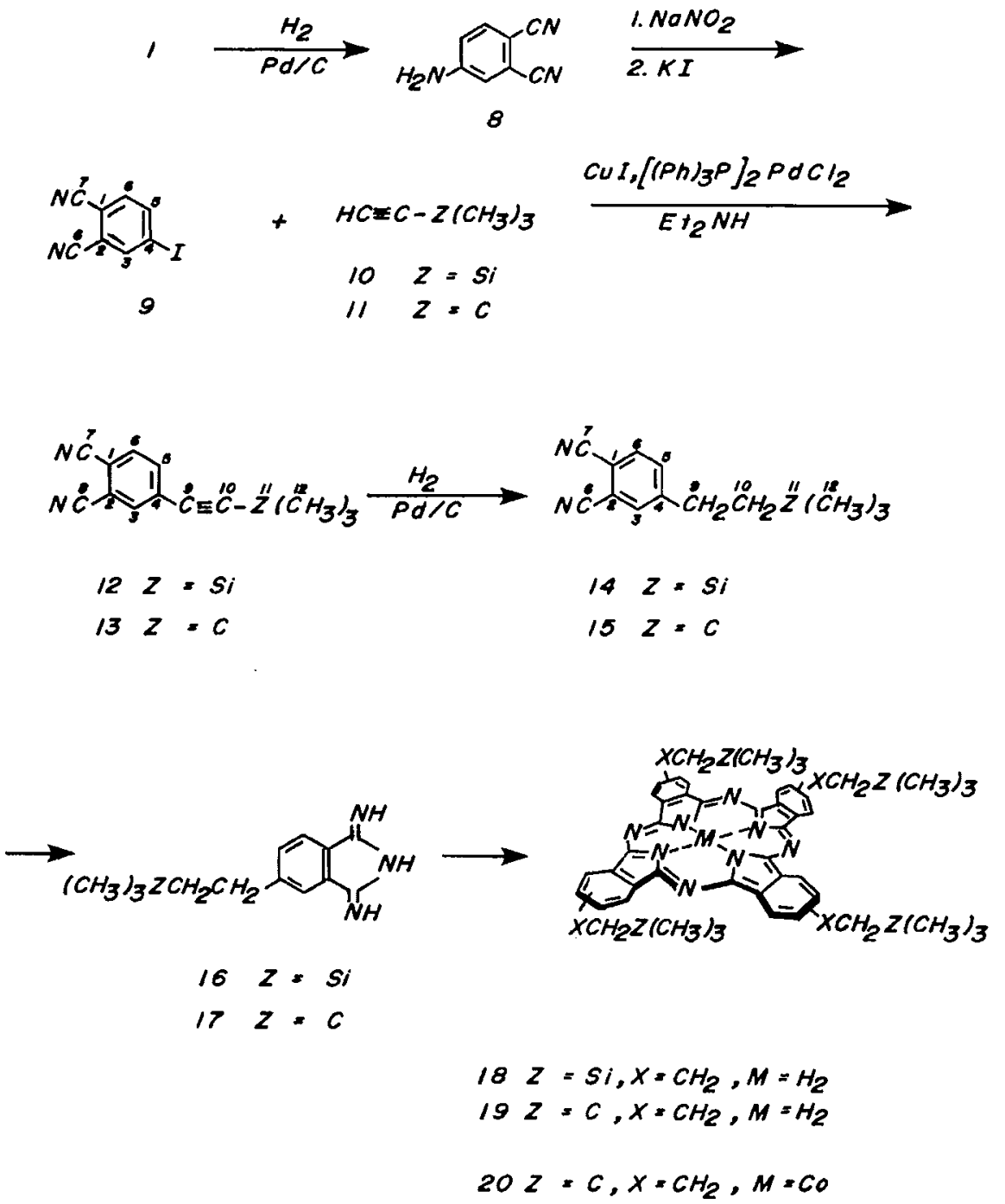

SCHEME 2

insoluble in most solvents except acetonitrile. Thus a suspension of 22 in acetonitrile was hydrogenated for $4 \mathrm{~h}$ at room temperature with shaking over $10 \%$ palladium on charcoal to give, in $83 \%$ yield, 1,2-bis-(3,4-dicyanophenyl)ethane (23). Compound 23 was converted to its 1,3-diiminoisoindoline (24) as before $(5,6,11,12)$ and condensed with an excess of the 1,3-diiminoisoindolines 16,17 , or 5 to give, after chromatographic separation, large amounts of the mononuclear phthalocyanines 18,19 , or 6 and $7-10 \%$ yields of 1,2-bis-2'-(9',$16^{\prime}, 23^{\prime}$-tri-(2-trimethylsilylethyl)phthalocyaninyl)ethane (25), 1,2-bis-2' - $\left(9^{\prime}, 16^{\prime}, 23^{\prime}\right.$-tri-(3,3-dimethylbutyl)phthalocyaninyl)

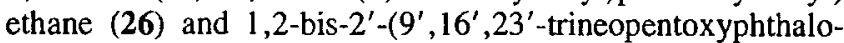
cyaninyl)ethane (27), respectively. Metal-free phthalocyanine 27 was readily converted to its dicobalt(II) derivative (28) $(6,11)$ (Scheme 3).

Binuclear phthalocyanines 25-27 exhibited the typical absorption spectra of metal-free binuclear phthalocyanines (6) while 28 exhibited the typical absorption of a metalated phthalocyanine dimer (Table 2). Compounds 25-28 all exhibited parent ions in their mass spectra using the $\mathrm{FAB}$ technique (14). Phthalocyanine dimers $25-28$ were very much less soluble in organic solvents than the four-atom bridged catechol type dimers described above and the previously described five-atom bridged dimers (Table 2). The ' $\mathrm{H}$ nmr of 25-27 were taken in dilute solutions and exhibited broad absorptions at the appropriate peak positions for the substituent groups (Table 3 ). The ${ }^{1} \mathrm{H} \mathrm{nmr}$ spectra of the inner $\mathrm{NH}$ protons of 18, 19, and 6 are dependent on concentration, solvent, and temperature (Table 3). As a result of our initial examination of these effects on the ${ }^{1} \mathrm{H}$ nmr of 6 (Table 3), we generally run our samples in $\mathrm{CDCl}_{3}$ or toluene- $d_{8}\left(\mathrm{C}_{7} \mathrm{D}_{8}\right)$ at concentrations of $10^{-3}$ to $10^{-4} \mathrm{M}$ at room temperature. The effects of concentration, solvent, and temperature on porphyrin monomers and dimers have been studied and the effects noted here are consistent with those trends noted in porphyrin chemistry $(17,18)$.

Preparation of a binuclear phthalocyanine covalently linked by a tetramethylene bridge

As has been shown above in the preparation of 18, 4-iodophthalonitrile (9) can readily couple with trimethylsilylethyne (10) to give 12. Attempts to hydrolyze 12 as before (16) or by alternate procedures (19) resulted in solutions from which the desired 4-ethynylphthalonitrile $(29)^{3}$ could only be isolated in low yield. Hydrolysis of $\mathbf{1 2}$ under very mild conditions did 
TABLE 4. ${ }^{13} \mathrm{C}$ nuclear magnetic resonance chemical shifts in ppm $(\delta)$ of some saturated solutions of mononuclear and binuclear phthalocyanines (Pc) in $\mathrm{CDCl}_{3}$ at $22^{\circ} \mathrm{C}$

\begin{tabular}{|c|c|c|c|c|c|}
\hline \multirow[b]{2}{*}{$\mathrm{Pc}$} & \multicolumn{5}{|c|}{ Carbon type } \\
\hline & Aromatic & $\mathrm{CH}_{2} \mathrm{X}^{\mathrm{a}}$ & $\mathrm{CH}_{2} \mathrm{Pc}$ & $\mathrm{C}^{\prime} \mathrm{Bu}$ & $\left(\mathrm{CH}_{3}\right)_{3} \mathrm{Z}^{b}$ \\
\hline $6^{c}$ & $160.6,122.1,117.4,117.2$ & $78.6,78.4$ & - & 32.5 & 27.3 \\
\hline $6 \mathrm{Zn}{ }^{c}$ & $\begin{array}{l}160.1,149.5,121.7,121.3 \\
116.9,116.6,104.2,103.9\end{array}$ & $78.2,78.1$ & - & 32.2 & $27.1,26.8,26.5$ \\
\hline 18 & $\begin{array}{l}147.4(\mathrm{~m}), 146.3(\mathrm{~m}), 132.9(\mathrm{~m}) \\
\quad 128.3(\mathrm{~m}), 120.4(\mathrm{~m})\end{array}$ & $\begin{array}{l}19.3,19.2,19.1,19.0,18.9 \\
18.8,18.7,18.5\end{array}$ & $\begin{array}{l}31.0,30.95,30.8,30.7 \\
30.5,29.4\end{array}$ & - & $-1.35,-1.4$ \\
\hline 19 & $128.5,120.4$ & $30.8,30.7$ & 46.6 & $31.6,31.5$ & $29.7,29.6$ \\
\hline $7 a^{d, t e}$ & 160.9 & 78.5 & 一 & 32.2 & 27.1 \\
\hline $7 b$ & $f$ & 78.2 & - & 32.1 & $27.1,27.0,26.5$ \\
\hline $\begin{array}{l}25 \\
26\end{array}$ & $145.5,130.2,120.9^{f}$ & 18.9 & $31.3,29.7$ & 7 & $\begin{array}{l}-1.4,-1.5,-1.7 \\
29.7\end{array}$ \\
\hline 27 & $f$ & 77.2 & - & 31.9 & 26.9 \\
\hline $34^{x}$ & - & $77.8,77.3$ & 36.2 & $32.2,32.15$ & $27.4,27.2$ \\
\hline $35^{c . h}$ & $f$ & 78.6 & $f$ & 32.4 & 27.2 \\
\hline
\end{tabular}

“ $X=O$ for all compounds except $18,19,25$, and 26 where $X=\mathrm{CH}_{2}$.

${ }^{b} \mathrm{Z}=\mathrm{C}$ for all compounds except 18 and 25 where $\mathrm{Z}=\mathrm{Si}$.

'These data were taken from ref. 6.

"Weak absorptions at 31.8 and 26.5 are likely due to the bridging sert-butyl group.

'This measurement was done on a Bnsker WH400 instrument.

'The absorptions in this region were very weak.

'Weak absorptions at $26.8,26.73,26.7$, and 26.6 are likely due to bridging carbons.

"Weak absorptions at 30.1 and $26.6 \mathrm{ppm}$ are likely due to bridging carbons.
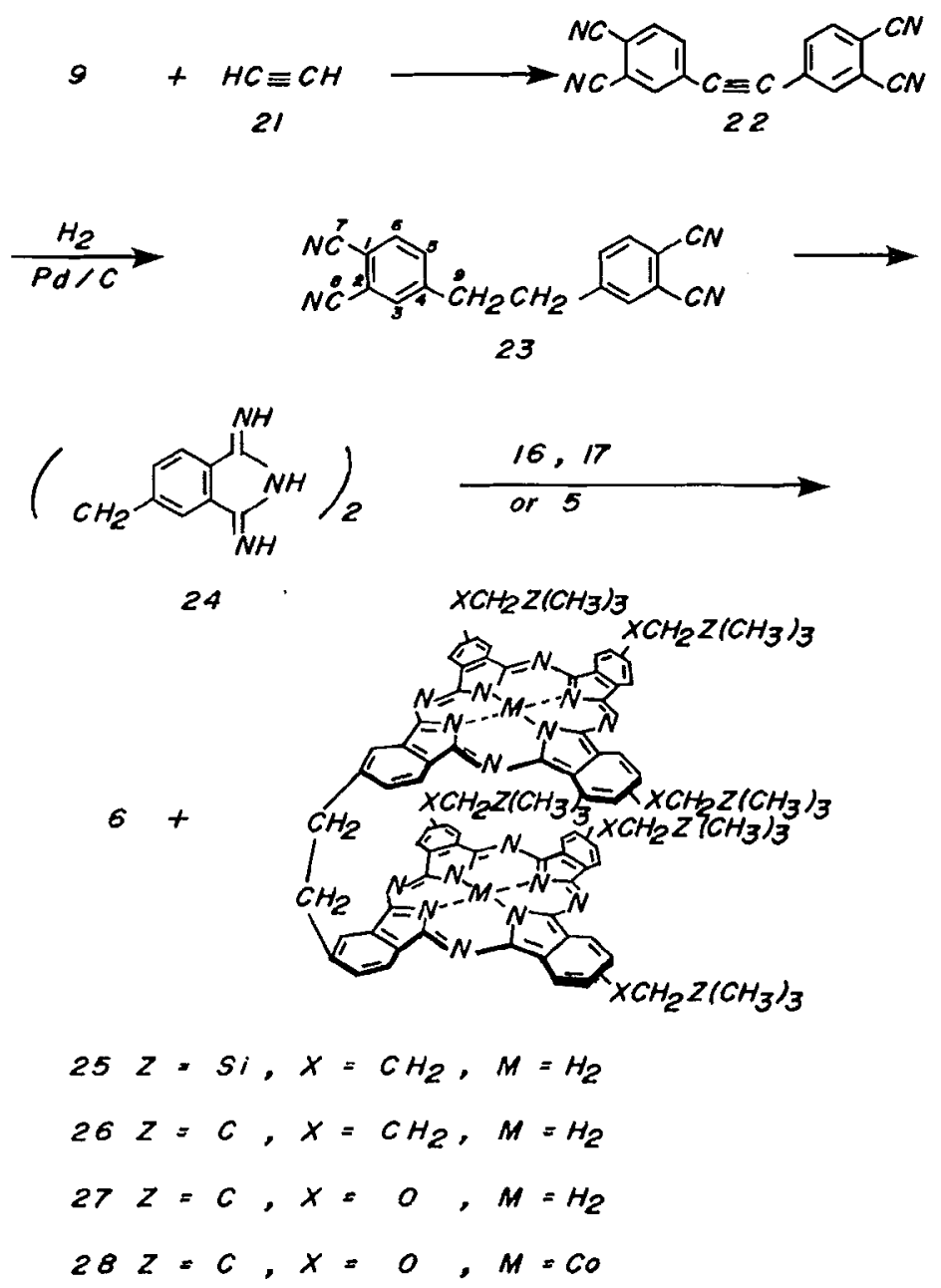

SCHEME 3 


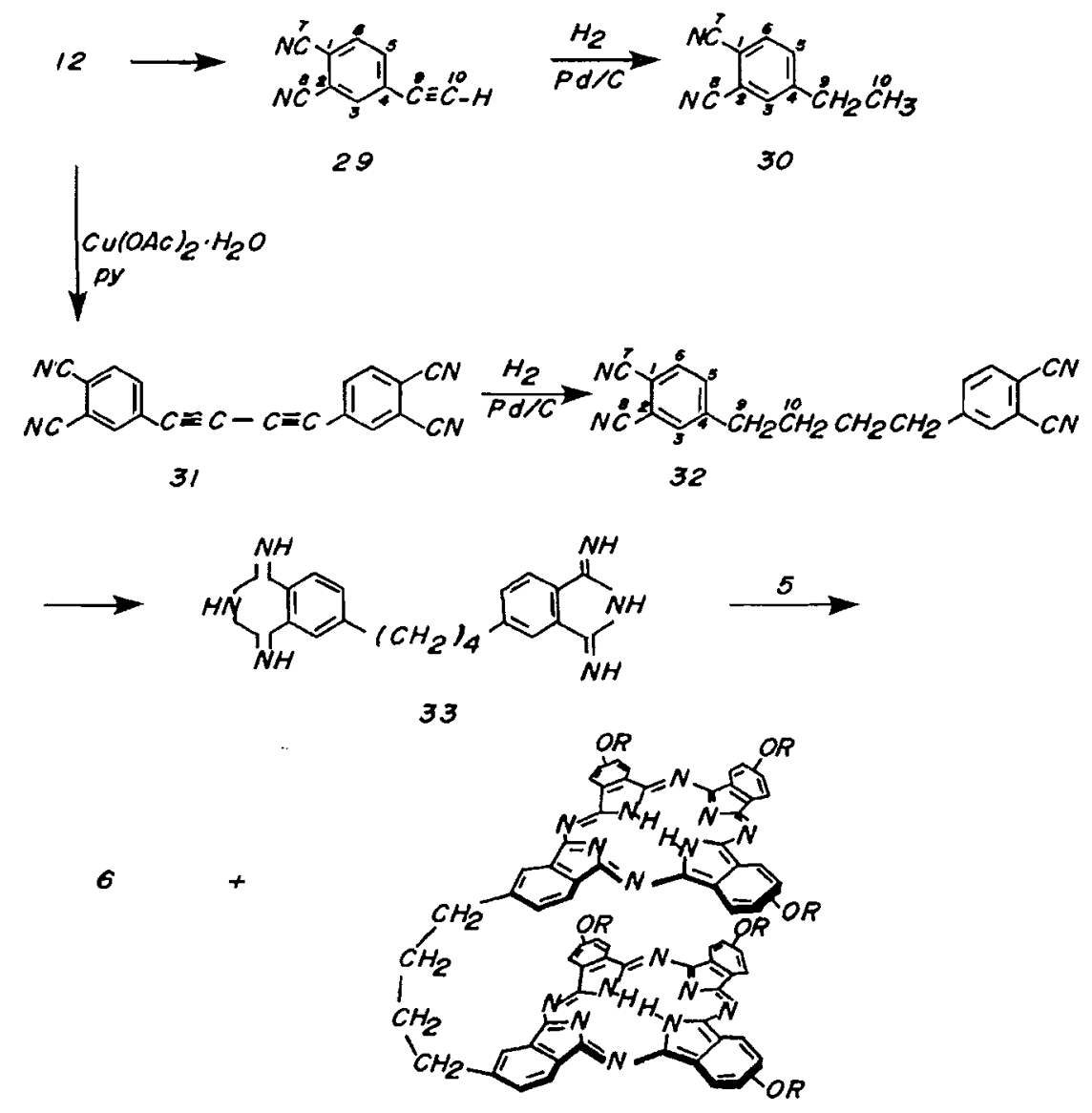

$34 R=\mathrm{CH}_{2} \mathrm{CrCH}_{3} \mathrm{H}_{3}$

SCHEME 4

proceed in methanolic pyridine or in pyridine- $\mathrm{Cu}(\mathrm{OAc})_{2}$ at room temperature to give 29 in high yield. Hydrogenation of 29 afforded 4-ethylphthalonitrile (30). ${ }^{3}$ Since we wished to perform an oxidative dimerization $(20,21)$ of 29 to give 1,4-bis(3,4-dicyanophenyl)-1,3-butadiyne (31) and since the conditions of this dimerization $\left(\mathrm{Cu}(\mathrm{OAc})_{2}\right.$, pyridine, methanol) are the very conditions that promote the hydrolysis of 12 to 29 , we felt that direct coupling of the precursor to 29 , i.e. 12, should give the desired product 31. Indeed, oxidative coupling of 12 yielded 31 in $76 \%$ yield. Catalytic hydrogenation of 31 as before gave 1,4-bis-(3,4-dicyanophenyl)butane $(32)^{3}$ in high yield. Conversion of 32 into its bis-1,3-diiminoisoindoline (33) as before $(5,6)$ and subsequent mixed condensation with 5 gave the undesired monomer 6 and the tetramethylene bridged dimer 1,4-bis-2' $-\left(9^{\prime}, 16^{\prime}, 23^{\prime}\right.$-trineopentoxyphthalocyaninyl). butane (34) in $1.4 \%$ yield (Scheme 4 ).

\section{Physical and spectroscopic properties of mononuclear and bi-} nuclear phthalocyanines

We have shown (6) that binuclear metal-free and metallophthalocyanine exhibit characteristic absorption spectra differing from each other and from the well-known absorption spectra of mononuclear metal-free and metallophthalocyanines (4). Thus, the mononuclear phthalocyanines 18-20 exhibit the characteristic absorptions (Table 2) of monomers, while binuclear phthalocyanines $7 a-c, 25-28$, and 34 all exhibit ab- sorptions more typical of dimeric phthalocyanines.

The visible spectra of $7 a, b, 25-27$, and 34 show double $\pi-\pi^{*}$ bands near 700 and $670 \mathrm{~nm}$, but the bands near 640 and $620 \mathrm{~nm}$ exhibit enhanced intensities compared to the model monomers 6, 18, and 19. In addition, compounds $7 c$ and 28 exhibit bands at 680 and $620 \mathrm{~nm}$ similar to the cobalt(II) derivative of 6 (5) and 20, but the intensity of the band at 620 is greatly enhanced, typical of aggregation $(22,23)$. Thus, the visible spectra of $7 a-c, 25-\mathbf{2 8}$, and 34 indicate substantial interaction between the phthalocyanine nuclei. This interaction is intramolecular rather than intermolecular since the blue shift is unaffected by dilutions in the range of $10^{-5}-10^{-6} \mathrm{M}$. A full description of the absorption and emission spectra of mononuclear and binuclear metal-free phthalocyanines is in progress.

As we have previously reported (6), the ' $\mathrm{H}$ nmr spectra of monomeric phthalocyanines such as 6 and dimeric phthalocyanines such as 1,3-bis- $2^{\prime}-\left(9^{\prime}, 16^{\prime}, 23^{\prime}\right.$-trineopentoxyphthalocyaninoxy)-2-ethyl-2-methylpropane (35) (Fig. I) and, now, dimers $7 a$ and $7 b$ exhibit broad absorptions for internal $\mathrm{NH}$ protons in the region of $-6.0 \mathrm{ppm}$ when the spectra are run on samples at high concentrations $\left(10^{-1} M\right)$ (Table 3). Although these data are consistent in general with those obtained by other workers for simple tetrasubstituted mononuclear phthalocyanines $(24,25)$, these workers do not record the concentrations of the phthalocyanines on which measurements were made and 


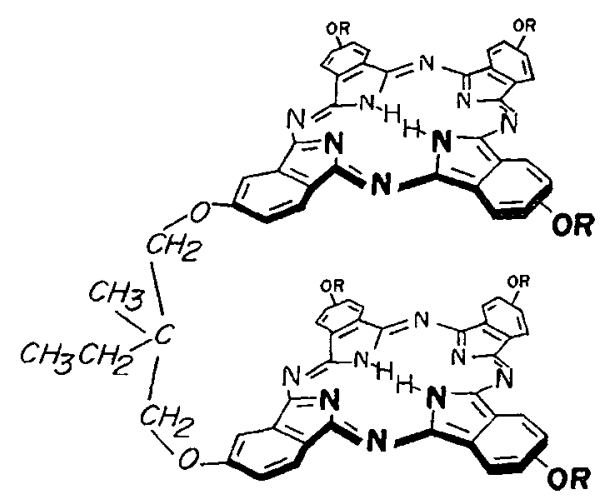

$\left.35 \mathrm{R}=\mathrm{CH}_{2} \mathrm{ClCH}_{3}\right)_{3}$

FIG. 1

the reported $\mathrm{NH}$ absorbances vary from $-2.0(24)$ to $-9.0 \mathrm{ppm}$ (25), an effect very concentration dependent as shown herein. The effect of concentration on the observance of the $\mathrm{NH} a b$ sorbances of 6 is described in footnote $d$ to Table 3 and effectively shows that the absorption changes from -5.5 at $10^{-1} \mathrm{M}$ to -3.0 at $10^{-3} M$ and remains constant upon further dilution. Furthermore, at intermediate concentrations $\left(10^{-2} M\right)$, the observation of two $\mathrm{NH}$ absorbances at -4.1 and -3.0 is noted and undoubtably represents a mixture of free and aggregated phthalocyanines. The effect of temperature on the ${ }^{1} \mathrm{H} \mathrm{nmr}$ of 6 is somewhat complicated by the concomitant effect of solvent on the internal $\mathrm{NH}$ absorbances. Thus in toluene- $d_{8}$ the $\mathrm{NH}$ absorbance (at $10^{-4} \mathrm{M}$ ) at $80^{\circ} \mathrm{C}$ is -3.0 , at $22^{\circ} \mathrm{C}$ is -2.60 , and at $-80^{\circ} \mathrm{C}$ is $-0.9 \mathrm{ppm}$. On the other hand, in $\mathrm{CD}_{2} \mathrm{Cl}_{2}$ the $\mathrm{NH}$ absorbance is invariant between $-70^{\circ} \mathrm{C}$ and $22^{\circ} \mathrm{C}$ and broadens greatly in $\mathrm{CDCl}_{3}$ at $50^{\circ} \mathrm{C}$. Most importantly, however, the higher temperature nmr spectra do not exhibit $\mathrm{NH}$ absorbances at significantly lower fields, and hence $10^{-3}-10^{-4} \mathrm{M}$ solutions most likely represent free non-aggregated phthalocyanines even at room temperature. The lack of an upfield shift of the $\mathrm{NH}$ absorbances at lower temperatures indicates that conformational mobility is still high enough that aggregation does not appreciably occur at -70 to $-80^{\circ} \mathrm{C}$. The $\mathrm{NH}$ absorbances of the binuclear phthalocyanines $(7 b)$ and 35 at $-70^{\circ} \mathrm{C}$ in $\mathrm{CD}_{2} \mathrm{Cl}_{2}$ and $+50^{\circ} \mathrm{C}$ in $\mathrm{CDCl}_{3}$ again do not appreciably change their value of $\sim-3.1 \mathrm{ppm}$, which indicates that even at low temperatures in the binuclear phthalocyanines conformational mobility is high on the nmr time scale or that intramolecular cofacial interaction is insignificant. Thus the extent of cofacial conformations of binuclear phthalocyanines $7 a, b, 25-27$, and 34-35 cannot be evaluated at present using nmr techniques. The mononuclear phthalocyanine 6 exhibits only a broad absorption peak for the $\mathrm{CH}_{3}$ groups of the tert-butyl substituent in its ' $\mathrm{H}$ nmr spectra at high concentrations $\left(10^{-1} M\right.$ ) (Table 3) (6) but in dilute solutions $\left(10^{-3}-10^{-4} M\right) 6$, the $\mathrm{Zn}$ derivative of $6(6 \mathrm{Zn})(6), 18(26)$, and 19 exhibit $6,7,4$, and 6 peaks, respectively, corresponding to this tert-butyl group. It should be noted that $6,6 \mathrm{Zn}, 18$, and 19 each exist as a mixture of four possible positional isomers and that these isomers give rise to a total of eight possible environments for the substituent groups. For dilute solutions, up to 7 of these different absorptions are seen for the tert-butyl group (Table 3). In fact, for $6 \mathrm{Zn}$ we can clearly see seven single absorptions for the $\mathrm{CH}_{2} \mathrm{O}$ group of the mixture of 4 isomers. For dimers $7 a, b, 25,26,27$, and 34 the ${ }^{1} \mathrm{H}$ nmr substituent absorbances of the mixtures of isomers are generally broad and not resolvable. As previously reported (6), the ${ }^{13} \mathrm{C}$ nmr of 6 at high concentrations $\left(10^{-1} M\right)$ exhibited only 1 absorption peak for the $\mathrm{CH}_{3}$ group of the tert-butyl group and, indeed, dimers $7 a, 7 b, 27$, and 34 , based on the neopentoxy substituent, all exhibited only one or two peaks for this group. On the other hand, the ${ }^{13} \mathrm{C}$ nmr of monomers 18 and 19 exhibited a multiplicity of peaks, again representing the 8 environments in which the four isomers each of 18 and 19 exist (Table 4). Indeed, 18 exhibits two absorptions for the $\mathrm{CH}_{3} \mathrm{Si}$ carbon, all eight absorptions for the $\mathrm{CH}_{2} \mathrm{Si}$ carbons, and six absorptions for the $\mathrm{CH}_{2} \mathrm{CH}_{2} \mathrm{Si}$ carbon (Table 4). The much greater multiplicity of isomers of the dimers and their even greater numbers of environments actually generate rather deceptively simple spectra in which single or small numbers of $\left(\mathrm{CH}_{3}\right)_{3} \mathrm{Z}$ absorbances are observed (Table 4). Because of this multiplicity of environments, rather poorly resolved, very weak, absorbances are observed in the aromatic region, and the bridging carbons of the dimers and these absorbances are not listed for both ${ }^{1} \mathrm{H}$ and ${ }^{13} \mathrm{C}$ nmr spectra of compounds in which these absorbances are poorly defined.

All phthalocyanines exhibited parent ions in their mass spectra (27) using the FAB system (14) and $o$-nitrophenyl octyl ether (ONPOE) as the solvent (6). The infrared spectra of all metal-free phthalocyanines exhibited characteristics $\mathrm{NH}$ absorptions at 3300 and $1020 \mathrm{~cm}^{-1}(28)$, which disappeared on formation of their cobalt derivatives.

The mononuclear phthalocyanine bearing the isohexyl substituents (19) was clearly less soluble than the tetraneopentoxyphthalocyanine (6) but the tetra-(2-trimethylsilylethyl)phthalocyanine (18) was almost as soluble as 6 (Table 2). Thus if one wishes to prepare soluble multinuclear phthalocyanines bearing no oxygen atoms around the periphery of the phthalocyanine nucleus, it would be possible to use isoindoline $\mathbf{1 6}$ as a "partner" in condensation reactions, but use of isoindoline 17 gives rather insoluble dimeric phthalocyanines (Table 2). It appears that phthalocyanine dimers containing bridges having oxygen atoms $(7 a, b, 35)$ are considerably more soluble than all carbon bridge dimers such as 25-27 and 34. Perhaps, not surprisingly, the more flexible tetramethylene bridged dimer 34 is more soluble than the ethylene bridged dimer 27 . Indeed, only dimers $7 a$ and 34 in this work exhibit ${ }^{13} \mathrm{C} \mathrm{nmr}$ peaks for bridging carbons (Table 4). It was not possible to measure the solubilities of all the phthalocyanines in the same solvent, as 6 and 18 are too soluble in $\mathrm{CHCl}_{3}$ or $o$-dichlorobenzene (ODCB) to conveniently obtain data while dimers 25-28 and 34 were generally totally insoluble in $\mathrm{CH}_{2} \mathrm{Cl}_{2}$. Using the knowledge that the phthalocyanines are generally soluble in solvents in the following order: $\mathrm{CDCl}_{3}>\mathrm{CHCl}_{3}>\mathrm{ODCB}>\mathrm{CH}_{2} \mathrm{Cl}_{2}$, we can generalize from the data shown in Table 2 that the order of solubility of monomeric and dimeric phthalocyanines is $6(6)>$ $18>6 \operatorname{Zn}(6)>35-7 b>19>20>34>27>25$ $>26>28$. Thus multinuclear phthalocyanines very soluble in organic solvents are most readily made using the 5-neopentoxyisoindoline 5, rather than the less accessible 5-alkylisoindolines 16 and $\mathbf{1 7}$, as a partner in mixed condensations with bisisoindolines. In addition, multinuclear phthalocyanines bridged only by carbon atoms are less soluble than their oxygen bridged analogs. This decreased solubility may render their electrocatalytic properties less amenable to study. Further research on the synthesis of binuclear and multinuclear phthalocyanines having a fixed cofacial structure is in progress.

\section{Experimental}

Matheson high purity argon was used to maintain inert atmosphere 
conditions. Infrared (ir) spectra were recorded on a Pye Unicam SP1000 infrared spectrophotometer using $\mathrm{KBr}$ discs for solids or as neat films between $\mathrm{NaCl}$ dises. Nuclear magnetic resonance (nmr) spectra for protons were recorded on a Varian LM 360 spectrometer using deuterochloroform as solvent and tetramethylsilane as the internal standard. The positions of the signals are reported in $\delta$ units. (The splittings of the signals are described as singlets (s), doublets (d), triplets (t), quartets (q), or multiplets (m).) A Bruker AM300 nmr spectrometer was used for all ${ }^{1.3} \mathrm{C} \mathrm{nmr}$ spectra and for ${ }^{\prime} \mathrm{H} \mathrm{nmr}$ spectra of all phthalocyanines unless otherwise stated. The ' $\mathrm{H} \mathrm{nmr}$ spectra of $10^{-4} M$ solutions of phthalocyanines were obtained by averaging $500-1000$ scans over the absorption range, while ${ }^{13} \mathrm{C}$ nmr spectra on saturated solutions of phthalocyanine were obtained by averaging $5000-15000$ scans over the absorption range.

The visible-ultraviolet spectra (uv) were recorded on a Hewlett Packard HP845I A Diode Array spectrophotometer. Mass spectra (ms) were recorded at $70 \mathrm{eV}$ on a VG Micromass $16 \mathrm{~F}$ mass spectrometer in the $\mathrm{El}$ mode.

The FAB spectra were obtained with a Kratos MS-50 triple analyzer mass spectrometer equipped with a FAB ion source of standard Kratos design and an lon Tech atom gun. The sample was dissolved in chloroform and a microliter of the resulting solution added to a microliter of $o$-nitrophenyl octyl ether on the probe tip. The spectra of the molecular ions of the binuclear phthalocyanines were obtained by signal averaging up to 256 scans over the appropriate mass range. The number in parentheses after the indicated ion shows the percentage of the base peak represented by that ion. Melting points (mp) were determined using a Kofler hot stage melting point apparatus and are uncorrected. Thin-layer chromatography (tlc) was performed using silica gel $\mathbf{G}$ as the adsorbent. Flash chromatography was performed using silica gel of particle size $20-45 \mu \mathrm{m}$. All reactions were stirred with a magnetic stirrer. All solvents were freshly distilled before use. Microanalyses were performed by Guelph Chemical Laboratories Ltd., Guelph, Ont.

\section{1,2-Bis-(3,4-dicyanophenoxy)-4-tert-butylbenzene (3a) and 1,2-bis-} (3,4-dicyanophenoxy)benzene ( $3 \mathrm{~b})$

A solution of $3.90 \mathrm{~g}(22.5 \mathrm{mmol})$ of $1,1.66 \mathrm{~g}(10 \mathrm{mmol})$ of $2 a$, and $7.0 \mathrm{~g}(50 \mathrm{mmol})$ of anhydrous potassium carbonate $\left(\mathrm{K}_{2} \mathrm{CO}_{3}\right)$ in $25 \mathrm{~mL}$ of dry dimethylformamide (DMF) $(6,9)$ was stirred at room temperature for $36 \mathrm{~h}$. The reaction mixture was diluted with water ( 150 $\mathrm{mL}$ ), extracted with ethyl acetate, washed with saturated potassium carbonate, $4 \mathrm{M} \mathrm{HCl}$, water, and saturated sodjum chloride, and dried over magnesium sulphate. Evaporation of the solvent gave a brown oil, which on recrystallization from ethyl acetate - petroleum ether gave, in $84 \%$ yield, $3.51 \mathrm{~g}$ of $3 a, \mathrm{mp} 143-143.5^{\circ} \mathrm{C}$; ir $\left(\mathrm{cm}^{-1}\right): 2260$ (CN), 1595, 1575; ' $\mathrm{H}$ nmr $\left(\mathrm{CDCl}_{3}, 60 \mathrm{MHz}\right) \delta: 7.85-7.05(\mathrm{~m}, 9 \mathrm{H}$, ArH $), 1.35(s, 9 \mathrm{H}, t \mathrm{Bu}) ; \mathrm{ms}, m / z: 418\left(\mathrm{M}^{+}, 21\right), 537(20), 283(10)$, 243 (65), $240(100), 183(48), 144(19), 105$ (58). Anal. calcd. for $\mathrm{C}_{26} \mathrm{H}_{58} \mathrm{~N}_{4} \mathrm{O}_{2}$ : C 74.63, H 4.34, N 13.39; found; $\mathrm{C} 74.62, \mathrm{H} 4.33, \mathrm{~N}$ 13.31 .

Similarly, a solution of $3.90 \mathrm{~g}(22.5 \mathrm{mmol})$ of $1,1.1 \mathrm{~g}(10 \mathrm{mmol})$ of $2 b$, and $7.0 \mathrm{~g}$ ( $50 \mathrm{mmol}$ ) of $\mathrm{K}_{2} \mathrm{CO}_{3}$ in $25 \mathrm{~mL}$ of DMF was stirred for $36 \mathrm{~h}$ at room temperature. The reaction mixture was extracted with ethyl acetate and worked up as described above to give a crude crystalline product, contaminated by a small quantity of starting material 1. Column chromatography of this crude mixture on silica gel and elution with $1: 5$ ethyl acetate - petroleum ether gave 1. Further elution with $3: 2$ ethyl acetate - petroleum ether gave, in $78 \%$ yield, upon evaporation of the solvent and recrystallization from ethyl acetate - petroleum ether, $2.82 \mathrm{~g}$ of colourless needles of $3 \mathrm{~b}, \mathrm{mp}$ $189-190^{\circ} \mathrm{C}$; ir $\left(\mathrm{cm}^{-1}\right): 2260,1595,1572 ;{ }^{\prime} \mathrm{H} \mathrm{nmr}\left(\mathrm{CDCl}_{3}, 60 \mathrm{MHz}\right)$ $\delta: 7.80-7.00(\mathrm{~m}, 10 \mathrm{H}, \mathrm{ArH}) ; \mathrm{ms}, \mathrm{m} / z: 363(31), 362\left(\mathrm{M}^{+}, 100\right), 219$ (30). Anal. calcd. for $\mathrm{C}_{22} \mathrm{H}_{10} \mathrm{~N}_{4} \mathrm{O}_{2}$ : C 72.93, $\mathrm{H} 2.78, \mathrm{~N} 15.46$; found: C 73.07, H 2.56, N 15.48.

\section{Preparation of isoindolines $4 \mathrm{a}$ and $4 \mathrm{~b}$}

The bis-1,3-diiminoisoindolines $4 a$ and $4 b$ were prepared as previously described $(6,12)$. In a typical example $20 \mathrm{mg}$ of sodium was added to $40 \mathrm{~mL}$ of dry methanol under argon to form sodium meth- oxide. Nitrile $3 b(500 \mathrm{mg}, 1.38 \mathrm{mmol})$ was added and the oil bath heated to $60^{\circ} \mathrm{C}$ to dissolve the nitrile. Ammonia gas was bubbled into this solution as previously described (6) and the methanol evaporated to give crude $4 b$, which was used directly in the next step. An ir spectrum of the crude isoindolines must not exhibit any residual nitrile absorption.

\section{I,2-Bis-2'- $-\left(9^{\prime}, 16^{\prime}, 23^{\prime}\right.$-trineopentoxyphthalocyaninoxy)-4-tert- butylbenzene (7a) and $1,2-b i s-2^{\prime}-\left(9^{\prime}, 16^{\prime}, 23^{\prime}\right.$ trineopentoxyphthalocyaninoxy)benzene $(7 \mathrm{~b})$}

The crude bis-1,3-diiminoisoindoline (4a) and 5-neopentoxy-1,3diiminoisoindoline (5) obtained from $200 \mathrm{mg}(0.48 \mathrm{mmol})$ of $3 a$ and $2.5 \mathrm{~g}$ (11.68 mmol) of 4-neopentoxyphthalonitrile $(5,6)$ respectively, were heated at $150-160^{\circ} \mathrm{C}$ (oil bath) in $20 \mathrm{~mL}$ of $2-N, N$-dimethylaminoethanol for $60 \mathrm{~h}$ under an argon atmosphere by methods similar to those previously described $(6,12)$. The reaction mixture was cooled, poured into water, filtered, and washed repeatedly with water. The crude reaction mixture was dissolved in $200 \mathrm{~mL}$ of toluene and stirred at $70^{\circ} \mathrm{C}$ for $5 \mathrm{~h}$ with $100 \mathrm{~mL}$ of $1 \mathrm{MKOH}$. The reaction mixture was cooled; the organic layer was separated from the aqueous layer and washed with water and saturated sodium chloride, and dried over magnesium sulphate. The toluene solution containing the phthalocyanine mixture was preadsorbed onto silica gel for flash chromatography (13). Elution with $600 \mathrm{~mL}$ of toluene - petroleum ether $(5: 1)$ followed by elution with pure toluene gave three initial fractions (200 $\mathrm{mL}$ each) followed by fifteen $100-\mathrm{mL}$ fractions and, finally, two $1-\mathrm{L}$ fractions. The early fractions contained pure 2,9,16,23-tetraneopentoxyphthalocyanine (6), the middle fractions mixtures of 6 and $7 a$, and the final fractions mixtures of $7 a$ and another phthalocyanine thought to be a trinuclear phthalocyanine. The middle fractions containing 6 and $7 a$ were rechromatographed on fresh silica by flash chromatography using toluene as eluant. Again monomer 6 eluted first, some mixed fractions eluted next, and pure $7 a$ was finally isolated. All of $7 a$ was eventually recovered by rechromatography of all mixed fractions. The yield of monomer 6 recovered was $58 \%(1.45 \mathrm{~g})$. The final fractions containing dimer $7 a$ and a trimer ${ }^{4}$ were also separated by flash chromatography to give, in total, $108 \mathrm{mg}$ (13\% yield) of $7 a$ as a dark, blue, shining solid, $\mathrm{mp}>300^{\circ} \mathrm{C}$; ir $\left(\mathrm{cm}^{-1}\right): 3310$ $(\mathrm{NH}), 1620,1245,1100,1020(\mathrm{NH}) ; \mathrm{ms} \mathrm{m} / \mathrm{z}: 1707.8(100), 1706.8$ $\left(\mathrm{M}^{+}, 87\right)$. Anal. calcd. for $\mathrm{C}_{104} \mathrm{H}_{100} \mathrm{~N}_{16} \mathrm{O}_{8}: \mathrm{C} 73.13, \mathrm{H} 6.25, \mathrm{~N} 13.12$; found: C 72.97, H 6.32, N 13.57.

A small fraction of the dimer-trimer mixture was chromatographed on preparative tlc plates using toluene/2-methoxyethanol (200:1) as solvent. The slower moving blue-green fraction was extracted with toluene and finally purified by flash chromatography using toluene/ 2-methoxyethanol (50:1) as solvent to give a very small quantity of a blue green solid. Mol. Wt. (FAB ms) calcd. for $\mathrm{C}_{156} \mathrm{~N}_{154} \mathrm{~N}_{24} \mathrm{O}_{12}$ : $2556.9 \mathrm{l}$; found $2556.2(100), 2555.2\left(\mathrm{M}^{+}, 76\right)$.

Similarly, the crude bis-1,3-diminoisoindoline $(4 b)$ and 5 , obtained from $500 \mathrm{mg}(1.38 \mathrm{mmol})$ of $3 b$ and $7.5 \mathrm{~g}(35.0 \mathrm{mmol})$ of 4-neopentoxyphthalonitrile $(5,6)$, respectively, gave monomer 6 in the toluene fractions on flash chromatography of the crude product obtained from the reaction mixture. Further elution with toluene/ 2-methoxyethanol (100:1) and toluene/2-methoxyethanol (200:5) gave mixed monomer-dimer fractions and pure dimer fractions. Rechromatography of the mixed fractions gave a total of $3.15 \mathrm{~g}$ of pure monomer 6 in $42 \%$ yield and $222 \mathrm{mg}$ ( $10 \%$ yield) of pure dimer $7 b$ as a dark, blue, shining solid, $\mathrm{mp}>300^{\circ} \mathrm{C}$; ir $\left(\mathrm{cm}^{-1}\right)$ : $3310(\mathrm{NH}), 1625$, 1248, $1105,1020(\mathrm{NH})$; $\mathrm{ms} \mathrm{m} / \mathrm{z}:\left[651.8(100), 1650.8\left(\mathrm{M}^{+}, 61\right)\right.$. Anal. calcd, for $\mathrm{C}_{100} \mathrm{H}_{98} \mathrm{~N}_{16} \mathrm{O}_{8}:$ C 72.71, H 5.98, N 13.57; found: C $73.24, \mathrm{H} 5.98, \mathrm{~N} 13.19$.

\section{1,2-Bis-2'- $\left(9^{\prime}, 16^{\prime}, 23^{\prime}\right.$-trineopentoxyphthalocyaninoxycobalt(II))ben- zene $(7 \mathrm{c})$}

A solution of $100 \mathrm{mg}(0.06 \mathrm{mmol})$ of $7 b$ and $80 \mathrm{mg}$ of cobalt(II) chloride in $10 \mathrm{~mL}$ of toluene/2-methoxyethanol (7:3) was heated at $110^{\circ} \mathrm{C}$ under argon for $30 \mathrm{~h}$ as previously described (6). Flash chromatography of the crude product using toluene/2-methoxyethanol (50:1) as eluant gave, in $69 \%$ yield, $73 \mathrm{mg}$ of $7 c$ as a shiny blue solid, $\mathrm{mp}>300^{\circ} \mathrm{C}$; ir $\left(\mathrm{cm}^{-1}\right): 1620,1250,1105,1070,760 ; \mathrm{ms} \mathrm{m} / \mathrm{z}: 1765.6$ 
(100), $1764.6\left(\mathrm{M}^{+}, 62\right)$. Anal calcd. for $\mathrm{C}_{1000} \mathrm{H}_{94} \mathrm{~N}_{16} \mathrm{O}_{8} \mathrm{Co}_{2}: \mathrm{C} 68.06$, H 5.37, N 12.70, Co 6.68; found: C 68.21, H 5.54, N 12.34, Co 6.44

\section{4-Aminophthalonitrile $(8)$}

A suspension of $5.19 \mathrm{~g} \mathrm{(30} \mathrm{mmol)} \mathrm{of} \mathrm{4-nitrophthalonitrile} \mathrm{(1)} \mathrm{(29)}$ and $0.5-0.6 \mathrm{~g}$ of $10 \%$ palladium on charcoal in $150 \mathrm{~mL}$ of $95 \%$ ethanol was placed a $500-\mathrm{mL}$ jar in a Parr hydrogenation apparatus and hydrogenated at $415 \mathrm{kPa}$ according to the procedure of Rasmussen $e t$ al. (30). The crude product $\left(4.2 \mathrm{~g} . \mathrm{mp} 175-178^{\circ} \mathrm{C}\right.$ ) was chromatographed using normal grade silica gel. Elution with benzene - ethyl acetate $(3: 1)$ gave $3.6 \mathrm{~g}$ ( $84 \%$ yield) of pure white crystals of $8, \mathrm{mp}$ $179-180^{\circ} \mathrm{C}$ (lit. (30) $\mathrm{mp} 179-181^{\circ} \mathrm{C}$ ). Compound 8 does deteriorate on standing and is usually directly converted into compound $9 \mathrm{de}-$ scribed below.

\section{4-Jodophthalonitrile (9)}

A suspension of $4.29 \mathrm{~g}(30 \mathrm{mmol})$ of 8 in $60 \mathrm{~mL}$ of $2.5 \mathrm{M} \mathrm{H}_{2} \mathrm{SO}_{4}$ was cooled to $-10^{\circ} \mathrm{C}$. A solution of $2.4 \mathrm{~g}(34 \mathrm{mmol})$ of sodium nitrite in $5-8 \mathrm{~mL}$ of $\mathrm{H}_{2} \mathrm{O}$ was added dropwise with stirring, while the temperature of the mixture was kept at -10 to $0^{\circ} \mathrm{C}$. Stirring was continued at $0^{\circ} \mathrm{C}$ for $0.5 \mathrm{~h}$ to complete the reaction. The resulting mixture was rapidly filtered by suction filtration and the cool filtrate

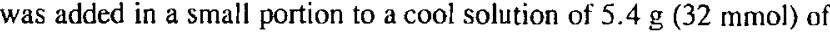
potassium iodide in $30 \mathrm{~mL}$ of water. The resulting black mixture was allowed to warm to room temperature with stirring. The precipitated black solid was collected by suction filtration, washed with cold water, and dissolved in benzene. The benzene solution was washed with cold water, $5 \% \mathrm{NaHCO}_{3}$, cold water, saturated $\mathrm{Na}_{2} \mathrm{~S}_{2} \mathrm{O}_{3}$, again with water, dried over $\mathrm{MgSO}_{4}$, filtered, and concentrated to a small volume. Chromatography on $200 \mathrm{~g}$ of normal grade silica gel and elution with benzene gave, in $70 \%$ yicld, $5.3 \mathrm{~g}$ of purc 9 as white crystals, mp $142-143^{\circ} \mathrm{C}$ (lit. (31) $\mathrm{mp} 141-142^{\circ} \mathrm{C}$ ); ir $\left(\mathrm{cm}^{-1}\right.$ ): $3020-2960,2240(\mathrm{CN}), 1580,940,850,845 ;{ }^{1} \mathrm{H} \mathrm{nmr}\left(\mathrm{CDCl}_{3}\right.$, $60 \mathrm{MHz}) \delta: 8.22-8.08(\mathrm{~m}, 2 \mathrm{H}, \mathrm{ArH}-3,6), 7.61-7.55(\mathrm{~m}, \mathrm{lH}$, ArH-5); ms $m / z: 254\left(\mathrm{M}^{+}, 87\right), 127(100), 100(38)$

\section{4-(2-Trimethylsilylethynyl)phthalonitrile (12) and 4-(3,3-dimethyl-1-} butynyl)phthalonitrile (13)

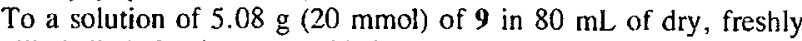
distilled diethylamine was added $2.1 \mathrm{~g}(22 \mathrm{numol})$ of tricthylsilylacetylene (10), $38 \mathrm{mg}(0.2 \mathrm{mmol})$ of copper(1) iodide, and $140 \mathrm{mg}$ $(0.2 \mathrm{mmol})$ of bis(triphenylphosphine)palladium dichloride under an argon atmosphere, using the procedure of Takahashi el al. (16). The reaction mixture was stirred at room temperature for $3 \mathrm{~h}$, during which time a precipitate of diethylamine hydroiodide appears. The mixture was filtered to separate the precipitated salt and the filtrate was concentrated on the rotary evaporator. The residue was extracted into benzene and purified by column chromatography on neutral alumina, activity II-III, using benzene as the eluting solvent. Evaporation of the solvent gave an oil which, on distillation in a Kugelrohr apparatus at $110-120^{\circ} \mathrm{C} / 0.01$ Torr $(1$ Torr $=133.3 \mathrm{~Pa})$, gave $3.4 \mathrm{~g}(75 \%$ yield $)$ of a white solid (12), $\mathrm{mp} 74-75^{\circ} \mathrm{C}$; ir $\left(\mathrm{cm}^{-1}\right): 3100,2240(\mathrm{CN}), 1600$, $1498,1440,1345,1265,1250,860,840 ;{ }^{\prime} \mathrm{H} \mathrm{nmr}\left(\mathrm{CCl}_{4}, 60 \mathrm{MHz}\right) \delta$ $7.65-7.52(\mathrm{~m}, 3 \mathrm{H}, \mathrm{ArH}), 0.05\left(\mathrm{~s}, 9 \mathrm{H},\left(\mathrm{CH}_{3}\right)_{3} \mathrm{Si}\right) ; \mathrm{ms} \mathrm{m} / \mathrm{z}: 224\left(\mathrm{M}^{+}\right.$, 17), 209 (100), 179 (14), 73 (70), 59 (27), 43 (23). Anal. calcd. for $\mathrm{C}_{13} \mathrm{H}_{12} \mathrm{~N}_{2} \mathrm{Si}$ : C $69.59, \mathrm{H} 5.39, \mathrm{~N} 12.49$; found: C $69.51, \mathrm{H} 5.53$, $\mathrm{N} 12.19$. Product 12 rapidly decomposed in the presence of water.

Similarly, a mixture of $2.54 \mathrm{~g}(10 \mathrm{mmol})$ of $9,0.82 \mathrm{~g}(10 \mathrm{mmol})$ of tert-butylacetylene (11), $20 \mathrm{mg}(0.1 \mathrm{mmol})$ of copper(I) iodide, and $140 \mathrm{mg}(0.2 \mathrm{mmol})$ of bis(triphenylphosphine)palladium dichloride in $50 \mathrm{~mL}$ of dry, freshly distilled diethylamine was stirred overnight under an argon atmosphere. Analysis by thin-layer chromatography (tlc), using ether-hexane 1:4 as eluant, showed the presence of unreacted 9. An additional $0.16 \mathrm{~g}$ of 11 was added and stirring was continued for a further $12 \mathrm{~h}$. A final addition of $0.16 \mathrm{~g}$ of 11 was added and, after stirring for a total of $72 \mathrm{~h}$, the reaction was still not completed. The reaction mixture was worked up as described above. Flash chromatography of the crude product using 1:19 ether-hexane as eluant gave an oil, which on distillation in a Kugelrohr apparatus at $130-135^{\circ} \mathrm{C} / 0.01$ Torr yielded $1.6 \mathrm{~g}$ (75\% yield) of pure 13 , mp $60-61^{\circ} \mathrm{C} ;$ ir $\left(\mathrm{cm}^{-1}\right): 3100,3000,2250(\mathrm{CN}), 2235,1600,1490$ $1370,1320,1275,910,880 ;{ }^{1} \mathrm{H} \mathrm{nmr}\left(\mathrm{CDCl}_{3}, 300 \mathrm{MHz}\right)$ 8: $7.77-7.67$ $(\mathrm{m}, 3 \mathrm{H}, \mathrm{ArH}), 1.32\left(\mathrm{~s}, 9 \mathrm{H},\left(\mathrm{CH}_{3}\right)_{3} \mathrm{C}\right) ; \mathrm{m} s \mathrm{~m} / z: 208\left(\mathrm{M}^{+}, 20\right), 193$ (100), 178 (13), 165 (18). Anal. calcd. for $\mathrm{C}_{14} \mathrm{H}_{12} \mathrm{~N}_{2}: \mathrm{C} 80.73$, H 5.81, N 13.45; found: C 80.70. H 5.90, N 13.21.

\section{4-(2-Trimethylsilylethyl)phthalonitrile (14), 4-ethylphthalonitrile (30), and 4-(3,3-dimethylbutyl)phithalonirile (15)}

A solution of $2.8 \mathrm{~g}(12.5 \mathrm{mmol})$ of $12 \mathrm{in} 50 \mathrm{~mL}$ of dry ethyl acetate was hydrogenated over $10 \%$ palladium on charcoal at $275 \mathrm{kPa}$ for $1 \mathrm{~h}$. The catalyst was filtered and the filtrate evaporated to dryness. Column chromatography of the product on $150 \mathrm{~g}$ of normal grade silica gel using ethyl acetate - hexane $(1: 4)$ as eluant gave, upon evaporation of the solvent, $2.5 \mathrm{~g}$ (88\% yield) of colourless needles. Distillation of the solid product in a Kugelrohr apparatus at $140-145^{\circ} \mathrm{C} / 0.1$ Torr gave pure $14, \mathrm{mp} 63-64^{\circ} \mathrm{C}$; ir $\left(\mathrm{cm}^{-1}\right): 3090,2970,2240(\mathrm{CN})$, $1605,1498,1345,1265,1250,860,840,700 ;{ }^{\prime} \mathrm{H} \mathrm{nmr}\left(\mathrm{CDCl}_{3}, 300\right.$ $\mathrm{MHz}) \delta: 7.60-7.45(\mathrm{~m}, 3 \mathrm{H}, \mathrm{ArH}), 2.7 \mathrm{l}(\mathrm{m}, 2 \mathrm{H}, \mathrm{CH}$ ArH), $0.84(\mathrm{~m}$, $2 \mathrm{H}, \mathrm{CH} \mathrm{CH}_{2} \mathrm{Si}, 0.01\left(\mathrm{~s}, 9 \mathrm{H},\left(\mathrm{CH}_{3}\right)_{3} \mathrm{Si}\right) ; \mathrm{ms} m / 2: 228\left(\mathrm{M}^{+}, 41\right), 213(35)$, 73 (100), 59 (68), 43 (17). Anal. calcd. for $\mathrm{C}_{13} \mathrm{H}_{16} \mathrm{~N}_{2} \mathrm{Si}$ : C 68.36, H 7.06, N 12.26; found: C 68.11, H 7.18, N 12.29 .

Further elution of the silica gel gave $0.1 \mathrm{~g}$ of 4-ethylphthalonitrile 30) as a white solid, $\mathrm{mp} 42-43^{\circ} \mathrm{C}$; ir $\left(\mathrm{cm}^{-1}\right): 3000-2900,2245(\mathrm{CN})$, $1600,1500,1240,1070,870,850$; ' $\mathrm{H} \mathrm{nmr}\left(\mathrm{CDCl}_{3}, 60 \mathrm{MHz}\right) \delta$ : $7.8-7.4(\mathrm{~m}, 3 \mathrm{H}, \mathrm{ArH}), 2.8\left(\mathrm{q}, J=8 \mathrm{~Hz}, 2 \mathrm{H}, \mathrm{CH}_{2}\right), 0.84(\mathrm{t}, J=$ $\left.8 \mathrm{~Hz}, 3 \mathrm{H}, \mathrm{CH}_{3}\right) ; \mathrm{ms} m / z: 156\left(\mathrm{M}^{+}, 50\right), 141(100), 114(40)$. Anal. calcd for $\mathrm{C}_{10} \mathrm{H}_{8} \mathrm{~N}_{2}$ : C 76.90, H 5.16, N 17.94; found: $\mathrm{C} 77.23$, H 5.33, N 17.99 .

Similarly, hydrogenation of $3.6 \mathrm{~g}(17 \mathrm{mmol})$ of 13 in $100 \mathrm{~mL}$ of dry ethanol for $1 \mathrm{~h}$ as described above yielded a crude oil. Flash chromatography of this oil using cther-hexane $(1: 9)$ as eluant and distillation of product using a Kugclrohr apparatus gave $3.3 \mathrm{~g}$ (92\% yield) of 15 as a colourless oil, bp $130-138^{\circ} \mathrm{C} / 0.01$ Torr; ir (neat, $\mathrm{cm}^{-1}$ ): $2980,2250(\mathrm{CN}), 1610,1500,1380,1250,850 ;{ }^{\prime} \mathrm{H} \mathrm{nmr}\left(\mathrm{CDCl}_{3}, 300\right.$ $\mathrm{MHz}) \delta: 7.80-7.78(\mathrm{~m}, \mathrm{JH}, \mathrm{ArH}), 7.65-7.58(\mathrm{~m}, 2 \mathrm{H}, \mathrm{ArH})$, 2.74-2.68 (m, 2H, CH 2 Ar) $1.54-1.48\left(\mathrm{~m}, 2 \mathrm{H}, \mathrm{CH}{ }_{2} \mathrm{C}\right), 1.33(\mathrm{~s}$, $\left.9 \mathrm{H},\left(\mathrm{CH}_{3}\right)_{3} \mathrm{C}\right)$. Anal. calcd. for $\mathrm{C}_{14} \mathrm{H}_{10} \mathrm{~N}_{2}: \mathrm{C} 79.20, \mathrm{H} 7.59, \mathrm{~N} 13.20$; found: $\mathrm{C} 79.05, \mathrm{H} 7.49, \mathrm{~N} 13.05$.

Preparation of 5-(2-trimethylsilylethyl)-1,3-diiminoisoindoline (16) and 5-(3,3-dimethylbutyl)-1,3-diiminoisoindoline (17)

All diiminoisoindolines were preparcd as previously described $(5$, $6,11,12)$. In a typical example $115 \mathrm{mg}(0.50 \mathrm{mmol})$ of 14 was added to a solution of $15 \mathrm{mg}$ of sodium in $10 \mathrm{~mL}$ of dry methanol. The mixture was stirred at room temperature for $1 \mathrm{~h}$ and for $4 \mathrm{~h}$ under reflux conditions, during which ammonia gas was bubbled into the solution. Evaporation of the solvent gave crude 16, which was used directly in condensation reactions without further purification. Compounds 16 and 17 did not exhibit nitrile absorptions in their ir spectra.

Preparation of 2,9,16,23-tetra-(2-trimethylsilylethyl)phthalocyanine (18) and 2,9,16,23-tetra-(3,3-dimethylbutyl)phthalocyanine (19)

The crude diiminoisoindoline 16 , obtained from $115 \mathrm{mg}(0.50$ mmol) of 14 in $2 \mathrm{~mL}$ of $2-N, N$-dimethylaminoethanol, underwent self-condensation as previously described $(5,6,11,12)$ to give $60 \mathrm{mg}$ of a crude reaction product. Flash chromatography of this product using toluene as eluant gave, upon evaporation of the solvent, $33 \mathrm{mg}$ (28\% yield) of 18 as a dark bluc, shining solid; ir $\left(\mathrm{cm}^{-1}\right): 3310(\mathrm{NH})$, $1620,1255,1100,1015(\mathrm{NH}), 870,840,760 ; \mathrm{ms} \mathrm{m} / \mathrm{z}: 915\left(\mathrm{M}^{+}\right.$, 100), 841 (28). Anal, calcd. for $\mathrm{C}_{52} \mathrm{H}_{60} \mathrm{~N}_{8} \mathrm{Si}_{4}:$ C 68.22, H 7.27, N 12.24; found: C 68.31, H 6.99, N 12.24.

Similarly, the crude diiminoisoindoline 17 , obtained from $118 \mathrm{mg}$ $(0.56 \mathrm{mmol})$ of 13 in $2 \mathrm{~mL}$ of $2-N, N$-dimethylaminocthanol, underwent self-condensation as previously described $(5,6,11,12)$ to give $90 \mathrm{mg}$ of a crude reaction product. Flash chromatography of this product using toluene as eluant gave, upon evaporation of the solvent, $48 \mathrm{mg}$ (40\% yield) of 19 as a dark blue. shining solid; ir ( $\left.\mathrm{cm}^{-1}\right): 3320$ (NH), 1625, $1105,1020(\mathrm{NH}), 760 ; \mathrm{ms} m / z: 850\left(\mathrm{M}^{+}, 100\right), 791$ (35), 424 (47). Anal. calcd. for $\mathrm{C}_{56} \mathrm{H}_{66} \mathrm{~N}_{8}: \mathrm{C} 79.02, \mathrm{H} 7.82, \mathrm{~N} 13.16$; found: C 78.71, H 7.76, N 13.09. 
2,9,16,23-Tetra-(3,3-dimethylbutyl)phthalocyaninatocobalt(II) (20)

To a solution of $153 \mathrm{mg}(0.18 \mathrm{mmol})$ of 19 in $15 \mathrm{~mL}$ of toluene and $5 \mathrm{~mL}$ of 2-methoxyethanol was added $91 \mathrm{mg}(0.70 \mathrm{mmol})$ of anhydrous cobalt(II) chloride as previously described (6). The solution was stirred at $115^{\circ} \mathrm{C}$ (oil bath) under an argon atmosphere for $19 \mathrm{~h}$. The crude reaction mixture was cooled to room temperature and the solvent evaporated. Flash chromatography of the residue using toluene as the eluting solvent gave, in $48 \%$ yield, $78 \mathrm{mg}$ of $\mathbf{2 0}$ as a dark blue, shining solid; ir $\left(\mathrm{cm}^{-1}\right): 1625,1105,760 ; \mathrm{ms} \mathrm{m} / \mathrm{z}: 908\left(\mathrm{M}^{+}, 75\right), 850$ (21). Anal. calcd. for $\mathrm{C}_{56} \mathrm{H}_{64} \mathrm{~N}_{8} \mathrm{Co}: \mathrm{C} 74.07, \mathrm{H} 7.10, \mathrm{~N} 12.34$, Co 6.49; found: C 74.50, H 7.64, N 11.58, Co 6.50.

\section{1,2-Bis-(3,4-dicyanophenyl)ethyne (22) and 1,2-bis-(3,4- dicyanophenyl)ethane (23)}

By the procedurc described above for the preparation of 12 and $13,5.1 \mathrm{~g}(20 \mathrm{mmol})$ of $9,150 \mathrm{~mL}$ of dry, freshly distilled diethylamine, $38 \mathrm{mg}(0.2 \mathrm{mmol})$ of copper(I) iodide, and $70 \mathrm{mg}(0.1 \mathrm{mmol})$ of bis(triphenylphosphine)palladium dichloride was placed into a 250-mL two-necked flask, equipped with a magnetic stirrer, a condenser, and a gas inlet tube. The flask was flushed with argon and a moderate stream of dry acetylene was passed through the solution for $3 \mathrm{~h}$ at room temperature. The pale pink precipitate that was formed was collected by filtration from the brown solution. The crude product was washed with water, methanol, and ether, and air dried to give, in $90 \%$ yield, $2.5 \mathrm{~g}$ of $22, \mathrm{mp} 286-288^{\circ} \mathrm{C}$. This product is sufficiently pure that it can be used directly without further purification. Two recrystallizations of a small sample of $\mathbf{2 2}$ from acetonitrile gave colourless crystals of pure $22, \mathrm{mp} 296-297^{\circ} \mathrm{C}$; ir $\left(\mathrm{cm}^{-1}\right): 3090,2240$ (CN), 1600, 1500, 1260, 920, 865; ms m/z:278( $\left.\mathrm{M}^{+}, 100\right), 251$ (14), 224 (8), 149 (35), 139 (11), 85 (38), 57 (97), 43 (73). Anal. calcd. for $\mathrm{C}_{18} \mathrm{H}_{6} \mathrm{~N}_{4}: \mathrm{C} 77.69, \mathrm{H} \mathrm{2.17}, \mathrm{N} 20.13$; found: $\mathrm{C} 77.97, \mathrm{H} 1.96$, N 20.01. Compound 22 is very insoluble in common organic solvents and is only slightly soluble in boiling acetonitrile $(100 \mathrm{mg}$ in $50 \mathrm{~mL})$. The ${ }^{1} \mathrm{H}$ and ${ }^{13} \mathrm{C}$ nmr of 22 was not determined, as a suitable solvent was not found in which 22 was sufficiently soluble.

A suspension of $0.6 \mathrm{~g}(2.1 \mathrm{mmol})$ of 22 in $300 \mathrm{~mL}$ of acetonitrile, containing $100 \mathrm{mg}$ of $10 \%$ palladium on charcoal, was hydrogenated at $415 \mathrm{kPa}$ in a Parr hydrogenation bottle for $4 \mathrm{~h}$ at room temperature. The clear solution was filtered from the catalyst and concentrated. The compound was purified by flash chromatography using hot acetonitrile as eluant to give $0.5 \mathrm{~g}$ (83\% yield) of 23 as white needles, $\mathrm{mp}$ $257-258^{\circ} \mathrm{C}$; ir $\left(\mathrm{cm}^{-1}\right): 3100,2980,2240(\mathrm{CN}), 1600,1490,1390$, $1240,925,860 ;{ }^{1} \mathrm{H} \mathrm{nmr}\left(\mathrm{CD}_{3} \mathrm{CN}, 400 \mathrm{MHz}\right) 8: 7.81(\mathrm{~d}, J=8 \mathrm{~Hz}$, $2 \mathrm{H}, \mathrm{ArH}-5$ ), 7.76 (s, 2H, ArH-2), 7.58 (d, $J=8 \mathrm{~Hz}, 2 \mathrm{H}$, ArH-6), $3.05\left(\mathrm{~s}, 4 \mathrm{H}, \mathrm{CH}_{2}\right) ; \mathrm{ms} m / z: 282\left(\mathrm{M}^{+}, 31\right), 141$ (100), 114 (49), 57 (73), 39 (11). Anal. calcd. for $\mathrm{C}_{18} \mathrm{H}_{10} \mathrm{~N}_{4}: \mathrm{C} 76.58, \mathrm{H} 3.57, \mathrm{~N} 19.84$; found: C $76.76, \mathrm{H} 3.47, \mathrm{~N} 19.94$.

Preparation of the bis-1,3-diiminoisoindoline (24)

Compound 24 was prepared as previously described (6) for the preparation of 1,3-diiminoisoindolines derived from bisphthalonitriles only slightly soluble in methanol.

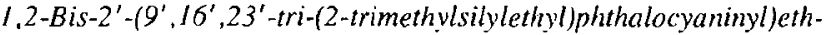 ane (25)}

The two crude diiminoisoindolines 16 and 24 , obtained from $4.80 \mathrm{~g}$ $(21.1 \mathrm{mmol})$ of 14 and $203 \mathrm{mg}(0.72 \mathrm{mmol})$ of 23 , respectively, in $30 \mathrm{~mL}$ of $2-N, N$-dimethylaminoethanol, underwent a mixed condensation as previously described $(5,6)$ to give $5 \mathrm{~g}$ of a crude reaction product. Flash chromatography on silica gel of this product on a $5-\mathrm{cm}$ diameter column using toluene-hexane $(1: 1)$ as eluant gave $1.63 \mathrm{~g}$ of the monomeric 18 in $34 \%$ yield. Further elution with toluene gave a fraction consisting largely of dimer. This dimer fraction was purified further by flash chromatography on a $3-\mathrm{cm}$ diameter column. Elution with toluene-hexane $(1: 1)$ removed all traces of monomer, as analyzed by thc using toluene as eluant. Further elution with toluene gave a blue solid containing a trace of impurities, detected by tlc analysis and visualization with uv light. The blue solid was freed of these impurities by washing with methanol to give, in $7 \%$ yield, $83 \mathrm{mg}$ of the binuclear phthalocyanine 25 as a dark blue, shining solid; ir $\left(\mathrm{cm}^{-1}\right): 3320(\mathrm{NH}), 1620,1260,1105,1020(\mathrm{NH}), 870,840,760 ; \mathrm{ms}$ $m / z: 1659(48), 1658(63), 1657(100), 1656(9 \mathrm{I}), 1655\left(\mathrm{M}^{+}, 65\right)$. Anal. ealcd. for $\mathrm{C}_{166} \mathrm{H}_{110} \mathrm{~N}_{16} \mathrm{Si}_{5}$ : C 69.61, H 6.69, N 13.53; found: C 69.65, H 6.80, N 13.16.

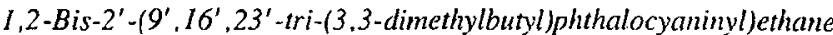

(26)

The two crude diiminoisoindolines 17 and 24 , obtained from $4.46 \mathrm{~g}$ $(21.0 \mathrm{mmol})$ of 15 and $203 \mathrm{mg}(0.72 \mathrm{mmol})$ of 23 , rcspectively, in $30 \mathrm{~mL}$ of $2-N, N$-dimethylaminoethanol, underwent a mixed condensation as described for $7 a, 7 b$, and 25 above and previously $(5,6)$ to give $5 \mathrm{~g}$ of a crude reaction product. Flash chromatography of this product on silica gel ( $5-\mathrm{cm}$ diameter column) using toluene-hexane $(1: 1)$ and pure toluene gave $2.07 \mathrm{~g}$ of the monomeric phthalocyanine 19 containing traces of dimer, as analyzed by tc using toluene as eluant. Further elution with 2-methoxyethanol/toluene $(1: 100)$ gave a fraction consisting largely of dimer containing traces of monomer. Finally, elution with 2-methoxyethanol/toluene (1:4) gave a green fraction consisting largely of trimer and impurities. The solid monomer fraction was placed in the thimble of a Soxhlet extractor and extracted with refluxing hexanes to give $0.52 \mathrm{~g}$ of pure monomer 19. Using the Soxhlet extractor and refluxing toluene as solvent, a further $0.71 \mathrm{~g}$ of 19 was isolated from the extracting solvent on evaporation, leaving $0.84 \mathrm{~g}$ of insoluble monomer containing traces of dimer in the thimble. It is possible that some of the positional isomers of 19 are more soluble than others and that the above selective extraction has effected a partial separation of these isomers. The dimer fraction was purified by vacuum liquid chromatography (vlc) (32) using toluenehexanes $(1: 1)$ as the eluting solvent followed by increasing amounts of 2-methoxyethanol/toluene $(1: 100$ to $5: 100)$. The vlc removed most of the monomer (but not all) and a final separation was achieved by flash chromatography (13) using the same eluting solvents as above to give, in $8 \%$ yield, $90 \mathrm{mg}$ of the pure binuclear phthalocyanine 26 as a dark blue, shining solid; ir $\left(\mathrm{cm}^{-1}\right)$; $3320(\mathrm{NH}), 1625,1105,1015$ (NH), 760; $\mathrm{ms} m / z: 1561(84), 1560(100), 1559\left(\mathrm{M}^{+}, 84\right)$. Anal. calcd. for $\mathrm{C}_{102} \mathrm{H}_{110} \mathrm{~N}_{16}$ : C 78.53, H 7.11, $\mathrm{N}$ 14.36; found: C 79.36, $\mathrm{H} 7.62$, N 13.49 .

\section{1,2-Bis-2'- $\left(9^{\prime}, 16^{\prime}, 23^{\prime}\right.$-trineopentoxyphthalocyaninyl)ethane (27)}

The two crude diiminoisoindolines 5 and 24 , obtained from $6.0 \mathrm{~g}$ (28 mmol) of 4-neopentoxyphthalonitrile $(5,6)$ and $284 \mathrm{mg}(1.0$ mmol) of 23 , were heated to $150^{\circ} \mathrm{C}$ (oil bath) in $30 \mathrm{~mL}$ of $2-N, N$. dimethylaminoethanol for $60 \mathrm{~h}$ under argon as previously described $(5,6)$. The crude product was purified by flash chromatography using a $5-\mathrm{cm}$ diameter column packed with silica gel $12 \mathrm{~cm}$ high. The crude product was preabsorbed on silica and eluted with toluene to give $2.67 \mathrm{~g}$ of the monomeric 6 in $44 \%$ yield. Further elution with 2 -methoxyethanol/toluene $(1: 100)$ gave a fraction consisting largely of dimer containing traces of monomer and some green material. Finally, elution with 2 -methoxyethanol/toluene (1:4) gave a green fraction consisting largely of trimer and impurities. The dimer fraction was further purified by flash chromatography (3-cm diameter column). Elution with toluene removed all traces of monomer. Further elution with 2-methoxyethanol/toluene $(5: 200)$ gave a dark blue product. This product was washed with acetone to remove traces of fluorescent and light green impurities, detectable by tlc using toluene/2-methoxyethanol (200:5) as eluant, to give in 10\% yield $159 \mathrm{mg}$ of 27 as a dark blue, shining solid; ir $\left(\mathrm{cm}^{-1}\right): 3310(\mathrm{NH}), 1620,1245,1100$, $1020(\mathrm{NH}), 755 ; \mathrm{ms} \mathrm{m} / z: 1574.8(51), 1572.8(90), 1571.8(100)$, $1570.8\left(\mathrm{M}^{+}, 60\right)$. Anal. calcd. for $\mathrm{C}_{96} \mathrm{H}_{48} \mathrm{~N}_{16} \mathrm{O}_{6}: \mathrm{C} 73.35, \mathrm{H} 6.28$, N 14.26; found: C 73.08, H 6.34, N 14.19.

The "trimer" fraction was further purified by flash chromatography (3-cm diameter column). Elution with 2-methoxyethanol/toluene $(3: 200)$ removed all traces of dimer. Further elution with 2 -methoxyethanol/toluene 1:20 gave $280 \mathrm{mg}$ of a dark, blue, shining solid in $25 \%$ yield. This product was not characterized.

\section{I,2-Bis-2'- $\left(9^{\prime}, 16^{\prime}, 23^{\prime}\right.$-trineopentoxyphthalocyaninyl cobalt(II))ethane} (28)

A mixture of $44 \mathrm{mg}(0.028 \mathrm{mmol})$ of metal-free dimer 27 and 
$21 \mathrm{mg}(0.16 \mathrm{mmol})$ of anhydrous cobalt(II) chloride in $13 \mathrm{~mL}$ of a $1: 4$ mixture of 2-methoxyethanol/toluene was heated at $120^{\circ} \mathrm{C}$ for $20 \mathrm{~h}$ under an argon atmosphere. Flash chromatography of the crude reaction mixture on a $3-\mathrm{cm}$ diameter column of silica gel and elution with 2-methoxyethanol/toluene (1:20 and then 1:8) gave, in 55\% yield, $26 \mathrm{mg}$ of 28 as a dark blue, shining solid; ir $\left(\mathrm{cm}^{-1}\right): 1620,1245,1100$, $760 ; \mathrm{ms} \mathrm{m} / \mathrm{z}: 1687.6(49), 1686.6(80), 1685.6(100), 1684.6$ $\left(\mathrm{M}^{+}, 76\right), 1630.6(38), 1629.6(57), 1628.6(72), 1627.6(51)$. Anal.

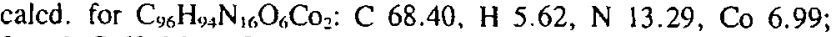
found: C 68.06, H 5.75, N 12.95, Co 7.19.

\section{4-Ethynylphthalonitrile (29)}

Preliminary experiments conducted on the hydrolysis of 12 to 29 showed that hydrolysis was slow in pyridine alone, pyridine and methanol, or pyridine and copper(II) acetate, and that all three components are necessary for rapid hydrolysis. These conditions are identical with those necessary for the coupling of terminal alkynes by the Eglinton procedure (20) except that hydrolysis occurs at room temperature. A solution of $0.09 \mathrm{~g}(0.4 \mathrm{mmol})$ of $12,1.6 \mathrm{~g}$ of copper(II) acetate monohydrate, $0.8 \mathrm{~mL}$ of methanol, and $14 \mathrm{~mL}$ of pyridine was stirred for $1 \mathrm{~h}$ at room temperature. The reaction mixture was filtered and washed with pyridine and methanol. The filtrate was evaporated to dryness in vacuo and extracted with methylene chloride. The extract was washed with water, dilute hydrochloric acid, and water, and dried over $\mathrm{MgSO}_{4}$. Evaporation of the solvent gave a product which was purified by flash chromatography, using ethyl acetate - hexane $(1: 4)$ as eluant. Evaporation of the eluant gave, in $82 \%$ yield, $50 \mathrm{mg}$ of pure 29 as white crystals, $\mathrm{mp} 88-90^{\circ} \mathrm{C}$; ir (Nujol, $\mathrm{cm}^{-1}$ ): 3280 (三C-H), 2250, 2135, 1600, 930, 850; ' $\mathrm{H} \mathrm{nmr}$ $\left(\mathrm{CDCl}_{3}, 60 \mathrm{MHz}\right) \delta: 8.0-7.8(\mathrm{~m}, 3 \mathrm{H}, \mathrm{ArH}), 3.45(\mathrm{~s}, 1 \mathrm{H}, \equiv \mathrm{C}-\mathrm{H})$; ms $m / z: 152\left(\mathrm{M}^{+}, 100\right), 125(46), 99(28), 74(26), 50$ (37). Anal.

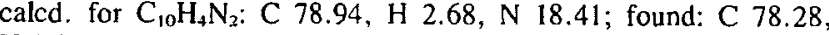
H 3.00, N 18.60 .

Further elution of the silica gel gave $10 \mathrm{mg}$ of $\mathbf{3 1}$ described below.

\section{1,4-Bis-(3,4-dicyanophenyl)-1,3-butadiyne (31)}

Using the Eglinton terminal alkyne coupling procedure (20) and recognizing that 12 gives 29 under the conditions of this reaction, $0.45 \mathrm{~g}(2.0) \mathrm{mmol}$ ) of 12 was mixed with $8.0 \mathrm{~g}$ of copper(II) acetate monohydrate in $70 \mathrm{~mL}$ of dry pyridine and $4 \mathrm{~mL}$ of dry methanol. The mixture was heated at $50-55^{\circ} \mathrm{C}$ for $0.75 \mathrm{~h}$ with stirring under argon. The reaction mixture was cooled to room temperature, filtered, and washed with pyridine and methanol. The filtrate was worked up as described for 29 above to give, in $76 \%$ yield, $0.23 \mathrm{~g}$ of a crude product, $\mathrm{mp} 299-302^{\circ} \mathrm{C}$. Further purification by flash chromatography on silica gel using $\mathrm{CH}_{2} \mathrm{Cl}_{2}$ as eluant gave, upon evaporation of the solvent, in $70 \%$ total yield $0.21 \mathrm{~g}$ of pure white crystals of $31, \mathrm{mp}$ $303-304^{\circ} \mathrm{C}$; ir $\left(\mathrm{cm}^{-1}\right): 3100,2250(\mathrm{CN}), 2180(\mathrm{C}=\mathrm{C}), 1600,1300$, $1240,925,860$; ' $\mathrm{H}$ nmr $\left(\mathrm{CD}_{2} \mathrm{Cl}_{2}, 60 \mathrm{MHz}\right) 8: 7.9-7.7$ (m, 6H, ArH); $\mathrm{ms} m / z: 302\left(\mathrm{M}^{+}, 100\right), 275(7), 248(5), 224(8), 200(8), 151(8)$, 124 (4), 98 (4), 74 (4). Anal. calcd. for $\mathrm{C}_{20} \mathrm{H}_{6} \mathrm{~N}_{4}: \mathrm{C} 79.46, \mathrm{H} 1.99$, N 18.54; found: C $79.39, \mathrm{H} 1.81, \mathrm{~N} 18.48$.

\section{1,4-Bis-(3,4-dicyanophenyl)butane (32)}

A solution of $0.15 \mathrm{~g}(0.5 \mathrm{mmol})$ of 31 in $100 \mathrm{~mL}$ of dry tetrahydrofuran (THF) and $50 \mathrm{mg}$ of $10 \%$ palladium on charcoal was hydrogenated at $275 \mathrm{kPa}$ in a Parr hydrogenator for $1 \mathrm{~h}$ at room temperature. The catalyst was filtered over Celite and washed with THF. The filtrate was evaporated to give fine colourless crystals in quantitative yield. Further purification by flash chromatography on silica gel using $\mathrm{CH}_{2} \mathrm{Cl}_{2}-$ ether $(1: 10)$ gave $0.13 \mathrm{~g}$ in $84 \%$ yicld of pure $32, \mathrm{mp} 168-169^{\circ} \mathrm{C}$; ir $\left(\mathrm{cm}^{-1}\right): 3100,2950,2240(\mathrm{CN}), 1600,1500$, $1250,860,850 ;{ }^{\prime} \mathrm{H} \mathrm{nmr}\left(\mathrm{CD}_{2} \mathrm{Cl}_{2}, 400 \mathrm{MHz}\right) 8: 7.73(\mathrm{~d}, J=8 \mathrm{~Hz}$, 2H, ArH-5), 7.62 (s, 2H, ArH-2), 7.53 (d, $J=8 \mathrm{~Hz}$, ArH-6), 2.77 $\left(\mathrm{t}, J=8 \mathrm{~Hz}, 4 \mathrm{H}, \mathrm{ArCH}_{2}\right), 1.67\left(\mathrm{~m}, 4 \mathrm{H}, \mathrm{CH}_{2}\right) ; \mathrm{ms} \mathrm{m} / \mathrm{z}: 310$ $\left(\mathrm{M}^{+}, 39\right), 169(26), 155(58), 141(100), 114(41), 39(13)$. Anal. calcd. for $\mathrm{C}_{20} \mathrm{H}_{94} \mathrm{~N}_{4}$ : C 77.39, H 4.55, N 18.05; found: C 77.62, $\mathrm{H} 4.35, \mathrm{~N} 17.97$.

\section{Preparation of the bis-1,3-diminoisoindoline (33)}

Compound $\mathbf{3 3}$ was prepared as previously described (6) for the preparation of 1,3-diiminoisoindolines derived from bisphthalonitriles only slightly soluble in methanol.

\section{1,4-Bis-2' $-\left(9^{\prime}, 16^{\prime}, 23^{\prime}\right.$-trineopentoxyphthalocyaninyl)butane (34)}

The two crude diiminoisoindolines 5 and 33 , obtained from $6.0 \mathrm{~g}$ (28 mmol) of 4-neopentoxyphthalonitrile $(5,6)$ and $310 \mathrm{mg}(1.0$ mmol) of 32 , respectively, were heated to $150^{\circ} \mathrm{C}$ (oil bath) in $30 \mathrm{~mL}$ of 2-N,N-dimethylaminoethanol for $60 \mathrm{~h}$ under argon as described for the preparation of 27 . Using a work-up identical to that for 27, purification by flash chromatography as before gave $1.64 \mathrm{~g}$ of monomer 6 in $27 \%$ yield and, in $1.4 \%$ yield, $23 \mathrm{mg}$ of dimer 34 as a dark blue, shining solid; ir $\left(\mathrm{cm}^{-1}\right): 3320(\mathrm{NH}), 1620,1250,1105,1020(\mathrm{NH})$, 760 ; ms $\mathrm{m} / \mathrm{z}: 1561.8$ (25), 1560.8 (85), 1599.8 (100), 1598.8 $\left(\mathrm{M}^{+}, 64\right)$. Anal calcd. for $\mathrm{C}_{98} \mathrm{H}_{102} \mathrm{~N}_{16} \mathrm{O}_{6}: \mathrm{C} 73.57, \mathrm{H} 6.42, \mathrm{~N} 14.01$; found: C $72.91, \mathrm{H} 6.62, \mathrm{~N} 13.65$.

\section{Acknowledgements}

We are grateful to the Natural Sciences and Engineering Research Council of Canada for financial support of this research. This work was also partially funded by the Office of Naval Research (Washington) and by the Midwest Center for Mass Spectrometry, a National Science Foundation Regional Instrumentation Facility (Grant No. CHE 8211164).

1. D. LeXa, P. Maillard, M. Momenteau, and J.-M. Saveant. J. Am. Chem. Soc. 106, 6321 (1984); P. SAYER, M. GOUTERMAN, and C. R. CONNELl. Acc. Chem. Res. 15, 73 (1982); P. Forswey, T. KuWana, N. Kobayashi, and T. Osa. Adv. Chem. Ser. 201, 601 (1982); J. ZAGal, P. BinORA, and E. YEAGER. J. Electrochem. Soc. 127, I506 (1980); F. VAN DEN BRINK, E. BARENDRECHT, and W. VisSCHER. Recl. Trav. Chim. Pays-Bas, 99, 253 (1980); K. KAsUEA and M. Tsursul. Coord. Chem. Rev. 32, 67 (1980).

2. J. P. Collman, F. C. Anson, S. Bencosme, A. Chong, T. Collins, P. Denisevich, E. Evitt, T. Geiger, J. A. Ibers, G. Jameson, Y. Konal, C. Koval, K. Meier, P. OAKLEY, R. B. PettMan, E. Schmittov, and J. Sessler. In Organic synthesis today and tomorrow. Edited by B. M. Trost and C. R. Hutchinson. Pergamon, Oxford. 1981

3. R. R. Durand, JR., C. S. Bencosme, J. P. Collman, and F. C. Anson. J. Am. Chem. Soc. 105, 2710 (1983).

4. A. B. P. Lever. Adv. Inorg. Chem. Radiochem. 7, 27 (1965).

5. C. C. LeznofF, S. GReEnberG, S. M. Marcuccio, P. C. Minor, P. SeYmour, A. B. P. LeVer, and K. B. TOMER. Inorg. Chim. Acta, 89, 135 (1984).

6. C. C. Leznoff, S. M. Marcuccio, S. GreenberG, A. B. P. LEVER, and K. B. TOMER. Can. J. Chem. 63, 623 (1985).

7. C. K. Chang, H. Y. LiU, and I. Abdalmuhdi. J. Am. Chem. Soc. 106, 2725 (1984); C. K. Chang and I. ABDalmuhDI. J. Org. Chem. 48, 5388 (1983).

8. J. T. ClerC, E. PretsCh, and J. Seibl. Structural analysis of organic compounds. Elsevier, New York. 1981. p. 277; G. C. LEVY, D. M. WhITE, and J. D. CARGIOLI. J. Magn. Reson. 8, 280 (1972).

9. W. O. SIEGL. J. Heterocycl. Chem. 18, 1613 (1981).

10. T. M. KELLER, T. R. PRICE, and J. R. GRIFFITH. Synthesis, 613 (1980); T. M. Keller and J. R. GRIFFITH. U.S. Patent No. $4,226,801$ (1980); N. P. MARULLO and A. W. SNow. ACS Symposium Series, 14, 325 (1982).

11. G. PAwlowSKI and M. HANACK. Synthesis, 287 (1980).

12. P. J. Brach, S. J. Grammatica, O. A. OsSana, and L. WeinBERGER. J. Heterocycl. Chem. 7, 1403 (1970).

13. W. C. StILL, M. KAHN, and A. Mitra. J. Org. Chem. 43, 2923 (1978).

14. M. BARBer, R. S. Bordoli, R. D. SEDGWICK, and A. N. TYLER. J. Chem. Soc. Chem. Commun. 325 (1981).

15. K. Sonogashira, Y. Tohoa, and N. Hagihara. Tetrahedron Lett. 4467 (1975)

16. S. Takahashi, Y. Kuroyama, K. Sonogashira, and N. Hagl- 
HARA. Synthesis, 627 (1980).

17. J. P. Collman, F. C. Anson, C. E. Barnes, C. S. Bencosme, T. Geiger, E. R. Evitt, R. P. Kreh, K. Meier, and R. B. PétTMAn. J. Am. Chem. Soc. 105, 2694 (1983).

18. R. J. AbRahAM and K. M. SMith. J. Am. Chem. Soc. 105, 5734 (1983); K. M. SMITH, R. J. ABrahaM, and H. PEarson. Tetrahedron, 38, 2441 (1982); T. R. JANSON and J. J. KATZ. In The porphyrins. Vol. IV. Edited by D. Dolphin. Academic Press, New York. 1979. p. 1.

19. C. S. Kraihanzel and J. E. Polst. J. Organometal. Chem. 8, 239 (1967); C. EABORN and D. R. M. WALTON. J. Organometal. Chem. 4, 217 (1965).

20. G. Eglinton and A. R. Galbraith. Chem. Ind. 937 (1956); G. Eglinton and A. R. Galbraith. J. Chem. Soc. 889 (1959).

21. H. Tani, F. Toda, and K. Matsumiva. Bull. Chem. Soc. Jpn. 36, 391 (1963); S. Akiyama and M. Nakagnwa. Bull. Chem. Soc. Jpn. 33, 1291 (1960).

22. A. W. Snow and N. L. Jarvis. J. Am. Chem. Soc. 106, 4706 (1984); R. D. Farina, D. J. Halko, and J. H. Swinehart. J. Phys. Chem. 76, 2343 (1972)

23. H. Sigel, P. WALdmeler, and B. PRiJs. Inorg. Nucl. Chem.
Lett. 7, 161 (1971); K. Bernauer and S. Fallab. Helv. Chim. Acta, 54, 1287 (1961).

24. M. Hanack, J. Metz, and G. Pawlowski. Chem. Ber. 115, $2836(1982)$

25. A. W. Snow, J. R. GRiffith, and N. P. Marullo. Macromolecules, 17, 1614 (1984).

26. B. L. Shapiro and T. W. Proulx. Org. Magn. Reson. 8, 40 (1976).

27. S. M. Schildcrout, J. Am. Chem. Soc. 105, 3852 (1983).

28. H. F. Shurvell and L. PInZuTi. Can. J. Chem. 44, 125 (1966); M. P. Sammes. J. Chem. Soc. Perkin Trans. 2, 160 (1972).

29. T. W. HAll, S. GreenberG, C. R. MCArthur, B. Khouw, and C. C. Leznoff. Nouv. J. Chim. 6, 653 (1982).

30. C. R. Rasmussen, J. F. Gardecki, J. N. Plampin, B. L. Twardzik, B. E. Reynolds, A. J. Molinari, N. Schwartz, W. W. BennetTs, B. E. Price, and J. J. Markowski. J. Med. Chem. 21, 1044 (1978).

31. T. M. Keller and J. R. GRIFFITH. U.S. Pat. 4,209,458 (1980); Chem. Abstr. 93, 221298a (1980).

32. N. M. Targett, J. P. Kilcoyne, and B. Green. J. Org. Chem. 44, 4962 (1979) 